\title{
EL VIAJE ARQUITECTÓNICO-ANTICUARIO DE FRAY JOSÉ ORTIZ Y SANZ: UNA CARTA ARQUEOLÓGICA DE ESPAÑA A FINES DEL XVIII
}

\section{THE ARCHITECTURAL-ANTICUARIAN JOURNEY OF FRAY JOSÉ ORTIZ Y SANZ: AN ARCHAEOLOGICAL SURVEY OF SPAIN IN THE LATE $18^{\text {TH }}$ CENTURY AD}

\author{
por \\ AliCia $\mathrm{M}^{\mathrm{a}} \mathrm{CANTO}^{1}$ \\ «Debo decir ahora que de mi escrito consta claro que siempre voy en busca de la verdad, \\ y en persecución de los errores, hállense en la pluma de quien se hallaren; \\ aquélla para confirmarla y seguirla; éstos para corregirlos si sé y puedo». \\ J. Ortiz y Sanz, Respuesta a Palos \\ y Navarro sobre Sagunto, $1812^{2}$
}

RESUMEN Fray Joseph Ortiz y Sanz (1739-1822), valenciano y liberal, es el más prolífico estudioso de la Antigüedad Clásica de la generación que sigue a la del marqués de Valdeflores, y el más afortunado en cuanto a la publicación de sus obras. Pero su proyectado Viaje arqueológico de España, aunque protegido durante años por Carlos III y Carlos IV, quedó inconcluso, como el de su noble predecesor. En este artículo se ponen de relieve la vida y obras de Ortiz, y se rescata y comenta el Proyecto de su viaje, publicado en 1797. Porél podemos conocer la formación y el trabajo de un arqueólogo de hace dos siglos pero, sobre todo, su inventario de casi 250 yacimientos ordenados por regiones, que pone en nuestras manos un novedoso mapa arqueológico de la España romana a fines del siglo XVIII. Una labor que nuestra nación-dicho sea de paso-tiene todavía pendiente de realizar.

\footnotetext{
1. Es una satisfacción para mí poder colaborar en este volumen de homenaje a la figura científica y humana de D. Manuel Pellicer Catalán, uno de mis más estimados maestros. De estudiante, en Madrid, ya eran modelos para nosotros los estudios del descubridor de Botorrita sobre los yacimientos granadinos de La Carigüela de Píñar y la necrópolis Laurita de Almuñécar. Cuando Manuel Pellicer llegó desde La Laguna a Sevilla para desempeñar la cátedra que había dejado Antonio Blanco al marchar a la Complutense, yo terminaba la carrera en el entonces «Seminario de Arqueología» hispalense. Le debo la dirección de mi Memoria de Licenciatura sobre el acueducto romano de Itálica -que él enriqueció dos años más tarde al excavar su castellum aquae-, así como una inolvidable (y sibarita) campaña de excavación en el cerro «Quebrantahuesos» de Riotinto, varios seminarios, estratigrafías muy útiles para mis propios estudios, otra visión de las arqueologías ibérica y celtibérica, o el ejemplo de su riguroso método. Pero quedaré sobre todo y siempre muy agradecida, a este aragonés sin fronteras, por muchos e impagables ratos de simposio en aquellos felices años, al calor de sus extraordinarias anécdotas y de su contagioso y fino humor.

2. Es la misma frase elegida por F. Goberna (2001: 5) al iniciar su biografía de Ortiz, resaltando (p. 6) que su vida fue «la recerca de la veritat $i$ com a conseqüència d'aquesta autoexigència, la inexcusabilitat de combatre els errors, la qual cosa, per altra part, li va suposar mès d'un disgust... aquesta actitud va ser també la pròpia dels més destacats il-lustrats espanyols...», la cual -concluye-fue la que hizo que España tuviera una mayor importancia dentro del movimiento ilustrado europeo.
} 


\begin{abstract}
Joseph Ortiz y Sanz (1739-1822), a valencias and a liberal, is the most prolific scholar of Classical Antiquity of the generation after that of marquis of Valdeflores, and the most fortunate in so far as the publication of his books is concerned. Nevertheless, his planned Archaeological Travel of Spain, although helped for years by Charles III and Charles IV, remained unfinished like that of his noble predecessor. In this article the life and works of Ortiz are highlighted and the plan of his itinerary -published in 1797-is transcript with some remarks. Through this we may know the training of an archaeologist two centuries ago, but above all his list of almost 250 archaeological sites arranged by regions, gives us a full of novelties map of Roman Spain at the end of the eighteenth century.
\end{abstract}

Palabras claves

Key words
Arqueología ilustrada española, siglo XVIII, Ortiz y Sanz, A. de Laborde, carta arqueológica, yacimientos hispanorromanos desconocidos.

Archaeology of Spanish Enlightenment, XVIIIth century, Ortiz y Sanz, A. de Laborde, archaeological inventory, hispano-roman unknown sites.

\title{
I. BREVE REFERENCIA A LA VIDA Y OBRAS DEL AUTOR, Y AZARES DE SU FALLIDO VIAJE ARQUEOLÓGICO DE ESPAÑA
}

Fray Joseph Francisco Ortiz y Sanz (Ayelo de Malferit 1739 - Valencia 1822) es uno de los más activos y prolíficos anticuarios de nuestro siglo XVIII, y también uno de los primeros entre los poquísimos españoles que viajaron a Italia (1778-1784) con el propósito de estudiar in situ las antigüedades romanas, en su caso sobre todo las arquitectónicas, que fueron uno de sus principales intereses vitales y científicos. Dejó demostradas sus cualidades como gran dibujante y buen teórico en sus traducciones comentadas de los tratados de Arquitectura clásica de Vitruvio y Palladio (Ortiz 1787, 1797a) o en sus póstumas Instituciones de Arquitectura Civil (1986), sin que dejaran de interesarle otros temas, como la Teología y la Filosofía, en las cuales se había graduado en su juventud (1849p), la Historia de España en general (1796-1802), la Cronología (1795-1798), o, entre sus obras menores, la historia del ejército romano (1817), el lugar de la batalla de Munda (1862p), la traducción de autores clásicos (1792) o, como resultado de una polémica, su nunca representada tragedia clásica en verso Orestes en Sciro (1790); ni olvidar asuntos más ligeros, como el que, inspirado en un pequeña opúsculo italiano, escribió como admonitorio para los que pudieran ser timados de los que corren el mundo a costa agena (Ortiz 1793). Pero fueron sus obras sobre la arquitectura clásica las que tuvieron mayor repercusión en la Arquitectura coetánea y posterior, puesto que fue a su través -y él mismo señala ese propósito-como los estudiantes de Arquitectura de la Real Academia de San Fernando pudieron conocer a fondo las formulaciones teóricas de Vitruvio y de Palladio, que tuvieron gracias a Ortiz un peso más decisivo en la arquitectura neoclásica española; son también éstas las que en el siglo XX han merecido lujosas reediciones.

El canónigo Ortiz, desde octubre de 1802 deán de la Colegial Mayor de Játiva (llamada por entonces San Felipe), bibliotecario real y académico de número de las de Historia y San Fernando, puede ser considerado como un personaje muy privilegiado dentro del elenco de los arqueólogos españoles de los siglos XVIII y aun del XIX. La obra y memoria de casi ninguno de ellos, en efecto, ha tenido ni remotamente su misma suerte: Durante su vida ya pudo disfrutar de la publicación de sus más grandes y costosas obras (1795-1803), algunas ilustradas con carísimos grabados (Ortiz 1787 y 1797a); llegaron a ver la luz también varios de sus trabajos póstumos (Ortiz 1849, 1862); los mejores de sus libros se han reeditado casi ininterrumpidamente, 
sobre todo durante el siglo $\mathrm{XX}^{3}$, algunos espléndidamente; $\mathrm{y}$, además, es objeto de recuerdo y honra en su ciudad natal, la valenciana Aielo de Malferit, donde cuenta con una calle ( $«$ del Canonge Ortiz») y preside la biblioteca pública (del «Degà Ortiz i Sanz»); incluso muy recientemente se ha iniciado allí, precisamente con su biografía detallada, una colección de publicaciones municipales a su nombre, en la que su más minucioso biógrafo (Goberna 2001, escudriñando por primera vez también en los ricos archivos locales) reasume y amplía trabajos anteriores $\left(1988\right.$ y 1998) ${ }^{4}$. Dentro de tan singular fortuna, en la eclosión historiográfica de estos últimos años la figura del deán ha sido tratada asimismo desde el punto de vista estrictamente arqueológico en algunas ocasiones, aunque no con la deseable profundidad (Matilla 1997; Mora 1998: 46-47; Canto 2001a: passim y lám. 10; Canto 2001b: passim ${ }^{5}$ ).

Así que realmente no se encuentra otro anticuario español de la Ilustración, ni uno posterior hasta el siglo XX, con tan buena fortuna a la hora de ser inmortalizada en vida su obra, o de encontrar reconocimiento en la posteridad. Sin duda ello se debe en su mayor parte al mérito de su propio esfuerzo, que fue formidable hasta casi los últimos momentos de su vida, y a la calidad y vistosidad intrínseca de sus trabajos. Pero puede también que el destino le reservara alguna especie de compensación, por las muchas veces que en su vida se halló escaso de medios económicos para desarrollar como él quería sus trabajos (hasta a veces para, según dice, el simple subsistir), mientras otros gastaban a manos llenas sin beneficio real para la Historia de la patria, de lo que él se queja algunas veces ( «...la fatalidad común de que siempre los amantes de este género de letras y expediciones carecen de caudales con los que sostener los gastos de viages, excavaciones, diseños, grabados de láminas, y demás anexos...», mientras se podía ver a los acaudalados «...derramar tesoros en vanidades, luxo, superfluidad, pasatiempos, bagatelas y otros bellísimos nadas...»); o también por las ocasiones en las que se lamentó de que su trabajo no era justamente reconocido, o incluso de que era aprovechado o plagiado por otros, quizá por ésos de los que corren el mundo a costa agena..., a los que se me ocurre que quizá quiso referirse indirectamente al traducir del italiano, en 1802, el citado opúsculo toscano.

El Archivo Histórico Nacional de Madrid conserva un voluminoso expediente ${ }^{6}$ con diversos documentos, fechados entre agosto de 1780 y el 26 de junio de 1802 , que reflejan una parte de las relaciones administrativas de Fr. José Ortiz con la Corona durante los reinados de Carlos III y Carlos IV, a través de diversos ministros (el conde de Floridablanca, Manuel Godoy, el marqués de Urquijo, Pedro Cevallos o José A. Caballero), o de diplomáticos españoles en Roma (el duque de Grimaldi y José Nicolás de Azara). Este expediente oficial se forma en 1802, y trae causa inmediata de la reiterada petición de Ortiz para dotarle de fondos para el Viaje anticuario de España, que hoy puede decirse que hubiera sido la mayor obra de su vida pero fue la más, y casi la única, fallida. Cuando en ese año, siendo uno de los cuatro académicos que componen la Comisión de Antiguiedades de la Real Academia de la Historia ${ }^{7}$, el presbítero propone a Carlos IV la consecución de su interrumpido viaje arqueológico y para ello le sugiriere distintas formas de proveerle de los medios necesarios para ello, alguien de la Secretaría de Estado, con muy pulcra letra, redacta un extracto para mejor noticia y decisión del rey, resumiendo las andanzas científicas y los distintos empleos

3. Véase al final la relación de obras de Ortiz con el detalle de sus numerosas reediciones hasta donde he podido rastrear.

4. Mi agradecimiento a la directora de la Biblioteca municipal de la hoy Aielo de Malferit, $\mathrm{D}^{\mathrm{a}} \mathrm{M}^{\mathrm{a}} \mathrm{Jesús}$ Juan Colomer, por todas las facilidades tan gentilmente dadas para este estudio.

5. Aprovecho aquí para corregir un muy lamentable error deslizado en mi citado libro 2001a (p. 185 y nota 159), al atribuir yo, por una confusión en mis fotocopias, el trabajo sobre Ortiz de 1997 a J.M. Medrano, cuando su autor real es J. M. Matilla.

6. Sección de Estado, leg. 3244. Lo hallé y vi la primera vez en 1997, para la investigación que hacía sobre la Arqueología española durante el reinado de Carlos IV y la privanza de Godoy (Canto 2001 a y b). Hay que advertir que se encuentran equivocadamente incluídos en este legajo de Ortiz y Sanz el expediente de una traducción del entonces muy novedoso libro de Adam Smith La riqueza de las naciones (por cierto que dedicada a Godoy) y un curriculum vitae, de 1792, que no corresponden a nuestro comentado arqueólogo, sino a su casi homónimo, y algunos años posterior (nació en 1755), el granadino licenciado en Leyes Joseph Alonso Ortiz.

7. Junto con Diego Clemencín, Joaquín Traggia y José Cornide, según él mismo afirma. 
y subvenciones que el presbítero había ido recibiendo a lo largo del tiempo. Este legajo, que contiene además varias cartas de mano del canónigo, junto a las referencias ya publicadas ${ }^{8}$, me ha servido de guía para recopilar aquí unas breves notas de su vida y obras, dentro de las cuales me detendré, como es lógico, en lo que afecta a tal viaje.

Nace, como dije, en Ayelo de Malferit (Valencia), el 5 de septiembre de 1739, quinto hijo, y mayor de los varones supérstites, de un matrimonio de acomodados labradores. El párroco de Ayelo, D. Patricio Ferrer, le enseña las primeras letras y se da cuenta de su precoz inteligencia y voluntad para el estudio. Se le envía por ello, y pensando ya en una futura carrera eclesiástica, al colegio de los jesuitas de Onteniente quienes, por un ejemplar acuerdo con el ayuntamiento, enseñaban gratuitamente la Latinitas; puede que esta inicial formación jesuítica no sea muy ajena en adelante a su mentalidad crítica y liberal. Yendo y viniendo de Onteniente, termina estos estudios iniciales de 1753 a 1755, y consigue en Valencia, a los dieciséis años, su título de Bachiller en Artes, que era el paso previo para el ingreso en la Universidad. Continúa en ella los estudios, ahora ya de Filosofía, en los mismos años en los que se crea la Real Academia de Santa Bárbara, futura de San Carlos. Su sobrino Tomás López Enguídanos, cuando muchos años después escribió su semblanza (Enguídanos 1824), anota que siguió entonces los cursos de dibujo que dicha Academia organizaba en las aulas de la Universidad, pero con la oposición de su padre, que no veía tales estudios artísticos adecuados para un futuro presbítero y le hizo por el momento abandonarlos.

Poco después, licenciado ya por Valencia en 1760, se trasladó a la Universidad de Orihuela para obtener el doctorado en Derecho Canónico y Civil, que logra brillantemente en 1764. Regresa a Valencia para estudiar Teología moral durante los siguientes tres años, y vuelve también a matricularse en los cursos de Dibujo arquitectónico de la ya Academia de San Carlos, lo que es prueba de su decidida vocación. En mayo de 1768, contando con 28 años, se ordena sacerdote e inicia un recorrido de destinos, como ecónomo, por distintas parroquias menores valencianas.

Por sus relaciones con la Academia valentina toma conciencia de la necesidad de una buena traducción directa al español de la obra de Vitruvio, a cuya gran utilidad para España el entonces monarca, Carlos III, hacía frecuentes referencias. Existía una versión castellana reciente, de J. Castañeda, publicada en 1761, pero se había hecho a partir de la francesa de Perrault (Mora 1988: 46), mientras la de M. Urrea, de 1582, aunque hecha del latín, estaba anticuada y era poco técnica. Cuando en 1774 se instala, ya con más tranquilidad, como vicario mayor de la iglesia colegial de Játiva (llamada por entonces San Felipe), concibe la idea de comenzar por sí mismo la traducción del importante arquitecto romano; ello fue, según el propio Ortiz, en 1777 (Ortiz 1787, Goberna 1998: 70). Pero, aun disponiendo de las versiones italianas de Philandro, Barbaro y Galiani, percibe la dificultad aneja de comprender bien los conceptos sin haber visto nunca edificios como los que Vitruvio comenta. Con un rey como Carlos III, venido de Italia, el ambiente en España era más propicio a favorecer las relaciones con aquel país, y Roma se hallaba en una época dorada para la Arqueología, la de Pío VI, como muy bien recuerda F. Goberna (1998: 72). Y es entonces cuando toma una de esas decisiones tan infrecuentes como admirables: renuncia a la vicaría saetabitana y vende parte de sus propiedades para trasladarse a Italia a sus expensas y poder realizar allí debidamente su estudio; para lo cual, en mayo de 1778 , se le concede el preceptivo permiso (pero véase infra).

El 27 de septiembre de 1778 llega a Roma tras un viaje de mes y medio, y dedica su primer año a visitar los más relevantes yacimientos y ciudades arqueológicas italianas. No será raro encontrar luego, en todas sus obras posteriores, evocaciones sueltas a estas experiencias, sea para aludir al estado de conservación de las pinturas pompeyanas, a la posibilidad de leer -icon no mucha dificultad, según él!- los famosos papiros herculanenses, o para otras incontables observaciones. En el verano de 1779, una vez instalado en Roma, se dedica, allí y en Florencia, a la consulta de los códices vitruvianos, y ocasionalmente hasta

8. Enguídanos 1824 [1921], Cubiles 1983, Rodríguez 1987, Matilla 1997, y, especialmente, la ya citada biografía que acaba de ser publicada por el Ayuntamiento de su ciudad natal (Goberna 2001). 
realiza algunas excavaciones en la Campagna, junto con otros pensionistas y estudiosos españoles. Dos años después, cuando él tiene ya cuarenta y dos, publica en Roma su primera obra, el Abaton Reseratum (Roma, 1781), en latín, dedicada a comentar dos pasos muy controvertidos de la obra de Vitruvio; es su presentación en el mundo científico, y directamente en el más cosmopolita, obteniendo buenas críticas de los expertos italianos (Goberna 2001: 35). Firma esta obra como Joseph Franciscus Ortiz, Presb(iterus) Hispano-Valentinus, y es notable que la imagen y el lema que presiden su portada ya hacen alusión a una de sus principales motivaciones vitales, puesto que la escena ilustra la frase de Ovidiofulget tenebris aurora fugatis (Met. II, 144), haciendo alusión ilustrada a cómo la luz de la verdad disipa las tinieblas del error.

De los antecedentes que existían en la Secretaría de Estado (AHN, leg. cit.) resulta que consiguió mantenerse por sí mismo en Italia durante año y medio. Entra luego en una época de penuria, en la que le ayudan algunos amigos y sus clases de latín y matemáticas. Cuando, muy apurado ya, en agosto de 1781, apela a la corte, se decide ayudarle con una subvención para los últimos 26 meses de su estancia, desde noviembre de 1781 a fines de 1783, a la vista del interés que tenía para España su trabajo. En este sentido hay en el expediente citado una curiosa carta -creo que de uno de nuestros representantes diplomáticos, el duque de Grimaldi-, de septiembre de 1781, de la que extracto estas frases: «...Incluyo el informe que hizo Azara acerca de este pobre clérigo y de su obra, se le debe proteger porque desde Felipe II acá España quiere tener una traducción del Vitruvio [...] según dice Azara, el tal valenciano es capaz de hacerla mejor que la italiana y la francesa, y ha entendido y explicado muy bien cosas que ellos [scil. Galiani y Perrault] no entendieron. [...] Parece difícil que se halle en mucho tiempo otro fanático como éste, y así juzgo muy conveniente proporcionarle algún medio de que lleve adelante su manía, y su obra se corrija y se imprima...». Aunque dicho en un lenguaje coloquial -que refleja bastante bien lo que a veces puede parecer a un político ajeno a nuestros estudios nuestra «manía» y «fanatismo» por las antigüedades-, lo cierto es que a partir de ahí el presbítero valenciano no sólo consiguió la regia protección -que, con altibajos, conservó hasta la salida de España de Carlos IV y Godoy en 1808-, sino que, con su obra de los cuarenta años siguientes, se ganó bien su fama posterior y demostró que no era, en definitiva, el «pobre clérigo» que el diplomático había diagnosticado.

El 8 de abril de 1784, el célebre José Nicolás de Azara, nuestro ya citado representante Roma, le hace entrega de 150 ducados con la condición expresa de que vuelva ya a España, a lo que parece que Ortiz se resistía pero hizo de Real Orden. Al volver e instalarse en Madrid, y mientras preparaba ya la edición de la obra vitruviana, que publicó efectivamente la imprenta regia (Ortiz 1787), solicitó vacante en la Biblioteca Real (dirigida en esos momentos por su amigo y paisano F. Pérez Bayer), que obtuvo en 1792, permaneciendo allí durante siete años, con un ascenso final a oficial $1^{\circ}$.

Fue durante su servicio en la Real Biblioteca (mayo de 1788 ) $^{9}$ cuando el padre Ortiz solicitó el permiso de Carlos III para emprender por primera vez su Viage arquitectónico-anticuario, que se le aprueba por Real Orden de 22 de junio de 1788, tras un informe favorable del conde de Campomanes desde la Academia de la Historia. No cabe duda de que, por su larga estancia en Italia, Ortiz estaba mucho más capacitado, no sólo para apreciar mejor las muchas antigüedades romanas que España atesoraba, sino la imperiosa necesidad de que fueran catalogadas, reconocidas personalmente y estudiadas con un método arqueológico riguroso. No ha de olvidarse en este punto que el anterior gran viaje anticuario de España, el del marqués de Valdeflores bajo Fernando VI, había quedado truncado al poco de iniciarse, e inéditos la mayoría de sus manuscritos. Con seguridad en este momento Ortizera sabedor de aquel viejo y gran proyecto del marqués arqueólogo, pero no podría conocer todos los escritos inéditos de D. Luis José de Velázquez, pues la mayor parte se hallaban aún en Málaga, fallecido su desdichado autor en 1772, y no llegarían a la Real Academia de la Historia hasta 1796 (Canto 1994: 512-514; allí permanecen).

9. En el legajo citado del AHN existe el borrador a mano del itinerario este primer proyecto (véase una lámina de su primera página en Goberna 1998: 75), que mantiene diversas diferencias con el finalmente publicado en 1797. 
Carlos III le concedió para el viaje «seis mil reales de las Rentas de Correos, por una vez» (AHN). Lo emprende, pues, de Real Orden, en julio de 1788, pero a un mes escaso, cuando se hallaba a 50 leguas de Madrid (Ortiz 1797: 11), dibujando en el Castell de Játiva (Goberna 1998: 74 y 2001: 53), tuvo la mala fortuna de contraer unas peligrosas fiebres cuartanas (típicas, aclara su biógrafo, de los cultivos de arroz de la zona), a causa de las cuales se temió incluso por su vida. Esto le hace aplazar por primera vez su viaje arqueológico, y regresar, a los cinco meses, a Madrid para terminar de curarse. Mientras tanto fallece, el 14 de diciembre de ese mismo año, su protector inicial, Carlos III.

Durante la convalecencia de aquellas fiebres aprovechó para traducir del griego la Vida de los filósofos ilustres, de Diógenes Laercio (Ortiz 1792), cediendo sus beneficios a la real imprenta (AHN, cit.). El 17 de marzo de 1790, como recuerda el mismo cronista (Goberna 2001: 56), y encontrándose más recuperado, envía un memorial al conde de Floridablanca para retomar el Viaje, otra vez por el reino de Valencia. Carlos IV, cuyo extraordinario y nada conocido interés por las antigüedades acabo de tener ocasión de resaltar (2001), accede igualmente, firmándole una Real Orden semejante a la de su padre, y consta que el 28 de septiembre se le libran otros 2000 reales. Pero nuestro canónigo -y es ahora quizá cuando pierde su mejor oportunidad de hacerlo- no lo emprende, porque recibe el encargo de poner las notas, prólogos y apéndices a los últimos tres tomos de la Historia de España de Juan de Mariana, impresos en Valencia (Ortiz 1791-1796). Por cierto que se valoró como un buen servicio a la Corona el que en esta continuatio Ortiz «ventiló el buen derecho con el que el Sr. Rey Don Fernando el Católico conquistó la Navarra Alta en 1512» (AHN, cit.). Se ocupó luego, hasta 1796, en escribir una Nueva Historia de España, de la que en 1802 se publicaría la $7^{\mathrm{a}}$ y última entrega, en octavo mayor. Tradujo, también por orden de Carlos IV, pero ahora del italiano, los Cuatro Libros de Arquitectura de Andrea Palladio, cuyo tomo I, publicado por la Real Imprenta en 1797, dedicado a Godoy, llevaba nada menos que 96 láminas; otras 20 quedaron grabadas para el tomo II, «para seguir cuando diga Su Majestad», aunque, dada la escasísima venta del tomo I, nunca se publicó la segunda parte, lo que es bien lamentable porque incluía muchas láminas de edificios romanos en Italia (Cubiles 1983: 154; Canto 2001a: 48 y nota 156, Goberna 2001: 72-73) ${ }^{10}$. Podemos apreciar, pues, cuán fructífera fue para él su estancia en la Biblioteca Real, donde pudo dedicarse con tranquilidad a sus trabajos científicos. Sin embargo, el gran viaje arqueológico seguía esperando, por más que el 28 de febrero de 1793 el rey le había concedido para ese fin otros 6000 reales (AHN).

A fines de 1796 (AHN) el canónigo presentó al monarca un nuevo proyecto para continuar el Viage, solicitando para ello 6000 reales al año, pero esta vez no se le concedió. Creo que Ortiz lo hizo alarmado al sospechar o comprobar que algunos franceses se disponían a realizarlo. En efecto, en este momento las circunstancias habían cambiado: Carlos IV y Godoy, interesados de verdad en que se celebrara de una vez aquella necesaria y diferida catalogación de las antigüedades españolas, habían dado entre tanto su aprobación y patrocinio al Voyage Pittoresque et Historique de l'Espagne propuesto por el hispano-francés (su padre era de Jaca, Huesca) Alexandre de Laborde.

Laborde querría repetir en España, un país de una riqueza arqueológica tan grande como desconocida para Europa, la feliz experiencia del precedente Voyage Pittoresque de la Grèce, realizado por M. G. A. Choiseul-Gouffier y cuyo primer volumen había aparecido en París, en 1782, para convertirse en el pionero y modelo de los llamados «voyages pittoresques» ilustrados, de carácter más bien romántico, aparte de catapultar a su autor, en aquel mismo año, a la embajada francesa en Constantinopla. Aunque en mi opinión existían muy buenos prototipos anteriores, y conocidos en Madrid, como las Remarks on Several Parts of Europe... Spain and Portugal de John (Durant de) Breval, de 1726 (Canto, e. e.), es probable que fuera la publicación del gran viaje de Grecia, que se produjo estando Ortiz en Roma y debió causar allí una gran

10. F. Goberna, ibid., que sin duda los ha buscado, señala que hoy no se conoce el paradero del manuscrito y las láminas de este segundo volumen. 
sensación, la que más directamente, también al canónigo, le diera la idea para su propio viaje anticuario de España.

Para el Voyage español de Laborde se formaría un amplio equipo, con españoles y franceses, que incluía dibujantes, grabadores y literatos: Carmona, Selma, Ametller, Enguídanos, Moulinier, Ligier, y, como historiadores, el agustino Fr. Juan Fernández de Rojas - continuador del P. Flórez- y Bernardo Cerat de Salvatierra, bibliotecario de San Isidro de Madrid. Laborde y Antoine de Boudeville, uno de los pintores de cámara de Carlos IV, dirigían en común esta que el propio futuro conde de Laborde llama en su portada «une société de gens de lettres et d'artistes de Madrid».

Manuel Godoy, Príncipe de la Paz -a quien fue dedicada inicialmente la ambiciosa obra-, en sus detalladas Memorias (1836: t. I, p. 217) consigna, en efecto, y ya en su primer periodo de gobierno, entre 1792 y 1798 , el patrocinio de este Voyage, que él se tomó como un empeño personal, «por su amor a las glorias de España» (Canto 2001: 49-56, para la españolidad de esta gran creación artística). Godoy no cita a este propósito el Viaje anterior de Fr. José Ortiz (al que elogia en otros pasajes de sus recuerdos), pero es muy lógico deducir que el rey y su secretario de Estado pensaron que la empresa superaba las posibilidades de un hombre solo, que contaba para entonces con casi sesenta años de edad, por mucho coraje que tuviera; que había comenzado e interrumpido el viaje dos veces en diez años, estaba tocado ya por una enfermedad recurrente, y además tenía entre manos varios otros empeños científicos de gran calado. Me parece claro que el análisis era acertado.

Ésta es, según creo, la verdadera razón por la que en 1797 se le denegaron el permiso y los medios para el viaje, alegando que no era urgente y que ya no se le podía asignar lo de 1790 (AHN cit., pero recordemos que aquellas subvenciones no las había llegado a emplear). A cambio, se le facilita una pensión para que ejecute el Plan de la Empresa. Éste es precisamente el folleto que aquí transcribiré y ésta, a mi juicio, la causa de que Ortiz resalte en el título que su proyecto era de 1790 , esto es, reafirmando su primacía sobre el de Laborde. Resultaría ser, además, otra prueba de que el viaje de este último, al revés de lo que suele creerse ${ }^{11}$, estaba ya en marcha antes de 1797 (Canto, ibid., para esta hipótesis y otros detalles); pero ahora, gracias a averiguaciones de F. Goberna, podemos concretar un terminus ante quem a comienzos de 1797.

En efecto, los días 21 y 22 de marzo de 1797 se publican dos referencias en el Diario de Madrid, firmadas con las iniciales «C.Y.J.P.». En ellas, el autor comenta el proyecto del viaje de Ortiz, al que éste se acaba de referir nuevamente en el volumen tercero de su Compendio cronológico de la Historia de España. Lo relaciona el ignoto columnista con el hecho de que hacía poco habían llegado a Madrid dos arquitectos y un pintor, los tres franceses, «para dibujar los planos y alzados de los edificios antiguos de España»; y se extrañaba de ello ya que, como según lo tenía planeado Ortiz, podían hacer esta empresa los mismos españoles. Como completa Goberna, dichos artistas galos eran Ligier, Moulinier y Vasalle, y durante su estancia en Madrid, a principios de 1797, los dos primeros se habían dirigido al canónigo para pedirle el itinerario de su viaje, con objeto de tener una guía y saber los monumentos que debían dibujar. Esto lo confirma el propio Ortiz en alguna ocasión, por ejemplo en un memorándum a Godoy, de 29 de marzo de 1802: «... y aun guiándose por mi plan, que dos de ellos me pidieron...». Podemos acaso imaginar que nuestro estudioso les facilitaría su itinerario muy a su pesar, pero porque ellos llevaran alguna nota en ese sentido, de la Secretaría de Estado. Por eso Ortiz recurre entonces a darlo cuanto antes a la imprenta.

Goberna (2001: 69) apunta la idea de que Godoy decidió dejar de prestar apoyo al plan de Ortiz porque le gustaba más el tipo de «viaje pintoresco» al uso en Europa desde comienzos del XVIII, debido a que éstos, dice, «presentaban de una manera agradable y, por tanto, poco crítica, el estado de estos monumentos antiguos y, en general, de España». Es una hipótesis interesante, que reflejaría una actitud muy propia de

11. Se repite, y también en el extranjero, que Laborde no vino a Madrid hasta 1800 , dentro del séquito de Lucien Bonaparte, y que la suya sería una obra patrocinada por Napoleón. En la obra citada defendí que Laborde tuvo que venir antes, entre 1792 y 1798, que llegó por su cuenta ante Godoy, y que fue éste quien apadrinó decisivamente la obra. La caída en desgracia posterior de Godoy y Carlos IV permitió borrar su mecenazgo y su protección de la empresa. 
algunos políticos, razón por la que no es del todo descartable. Pero hay otras referencias de época de por qué se prefería este tipo de viajes, con más ilustraciones que texto, y que combinaban «historia» y «poesía»; es en la recensión que F.-R. de Chateaubriand publicó en París sobre el libro de Laborde, cuando dice: «Toutefois, il est des parties dans l'histoire qui ne demandent pas le même courage dans l'historien. Les Voyages, par exemple, qui tiennent à la fois de la poésie et de l'histoire, comme celui que nous annonçons [scil., el de Laborde], peuvent être écrits sans péril. Et néanmoins les ruines et les tombeaux révèlent souvent des vérités qu'on n'apprendroit point ailleurs; car la face des lieux ne change pas comme le visage des homes...» (Chateaubriand 1807: 8).

Es cierto que los estudios arquitectónicos que Ortiz planeaba desarrollar serían más exactos y precisos, y desde luego más fiable su interpretación de cualquier edificio antiguo en ruinas, dada su amplia experiencia italiana y su conocimiento teórico desde Vitruvio. De hecho, ya tuve ocasión de observar, comparando las láminas de un experto técnico como Manuel de Villena con las de Laborde sobre monumentos de Mérida, que las de éste siempre resultan más bellas y románticas, pero menos exactas (2001: 55). Ahora bien, nunca llegaría a achacar la preferencia de Laborde sobre Ortiz a una voluntad cierta del Príncipe de la Paz de no presentar la Arqueología española tal cual era: Aparte de que, para un impaciente eficaz como Godoy, la lentitud del canónigo sería algo difícil de sobrellevar, pesaría en su ánimo el conjunto de razones de orden práctico que, como antes señalé, afectaban a éste, y que hacían ya poco viable-incluso ante nuestros ojos, hoy más imparciales- su proyecto viajero, como, por desgracia, el tiempo se encargó de demostrar.

Volviendo a Ortiz: en mayo de 1798 le ordena el rey quedar agregado a la Real Biblioteca como honorario, y el 13 de julio de 1798 (AHN) le otorga una prebenda: la «prestamera» de Beniel (Murcia), situada en el mismo límite con el reino de Valencia y dotada con 24000 reales anuales. En octubre de 1798 se le renueva el permiso para el viaje y las excavaciones que sean necesarias. En noviembre de 1799 se le retira la renta de 500 ducados que desde 1788 cobraba de Correos y se le pasa a bibliotecario honorario, esto es, con dispensa de la presencia efectiva. Parece claro que con ello se le ofrece casi una última posibilidad de realizar su viaje. Pero Ortiz se quejaría siempre de que la renta de Beniel no era suficiente para llevar a cabo su empresa «de viajar por varias provincias de la Península para reconocer las antigüedades romanas que existen en ellas y algunos célebres edificios modernos...». Es entonces cuando, moralmente obligado a presentar alguna acción concreta, como él mismo dice (AHN), «recogió 8000 reales $y$, con mucho esfuerzo, se fue a Sagunto a principios de 1800, e hizo la descripción de su teatro...». Midió, en efecto, y estudió, el famoso teatro romano, entre el 10 y el 23 de enero de $1800^{12}$, como también lo afirma en la obra (Ortiz 1807: nota 60), utilizando el por entonces novedoso procedimiento de la cámara oscura.

Este libro en gran formato trata, pues, con siete magníficos planos, alzados y dibujos, del teatro saguntino ${ }^{13}$, que poco antes (1790) también había estudiado y publicado en Dublín W. Cuningham, tesorero de la Real Academia Irlandesa. El volumen dedicado a la ciudad de los Escipiones, la joya de la arqueología valenciana, quedará así como único producto visible de su periplo anticuario, y aún con él, no completamente estudiada la ilustre Saguntum. Ya que -Ortiz mismo lo dice- «hubiera querido describir el gran circo, el templo de Hércules y otros admirables monumentos que aún subsisten en aquella ciudad...». Pero se le acabó el dinero y tuvo que regresar a Madrid.

En esta obra el deán nos confía que su Viaje «...no sólo vindicará en parte nuestro conocimiento en Artes y Anticuaria, sino que también puede acobardara los extranjeros del "Viaje Pintoresco de España", si son hombres que tienen alguna tintura de Anticuaria...» (esto es, de Arqueología), una clara puya dirigida al grupo de Laborde, que andaba, dice, lleno de indignación patriótica, «...haciendo lo que debieran los

12. Volvería otra vez allí entre el 6 y el 15 de junio de 1803: Ortiz, ibid. Sería curioso saber qué opinaría el deán hoy de su penosa (y polémica a posteriori) reconstrucción actual, $c f$. mi pequeño artículo «El teatro de Sagunto: la ruina de una ruina», diario Las Provincias, 8-6-1994.

13. Para la historia de las investigaciones sobre este edificio, véase la reciente monografía de S. Lara Ortega (1991). 
españoles...», y de los que temía que «...no siendo más que hombres curiosos, desflorasen nuestras antigüedades y las describiesen mal y diminutamente...», y aún eso teniendo suerte de que «no llenasen de burlas y sarcasmos sus relaciones, como acostumbran» (Goberna 2001: 67, del citado memorándum a Godoy).

Vuelve a Madrid para poner en limpio los dibujos y redactar los textos. Entre tanto, y ya casi completa la publicación de su Compendio, solicita y obtiene en 1801 el ingreso en la Real Academia de la Historia, disertando en aquella ocasión sobre el lugar de la antigua Munda: Ortiz no estaba de acuerdo con la tradicional ubicación en Monda (Málaga), y razonaba su localización, a tenor de las fuentes, entre Osuna y Écija o, como segunda alternativa, cerca de Estepa y en la ribera derecha del Genil.

Llegamos así a la fecha del expediente varias veces citado del Archivo Histórico Nacional, del que también trata Goberna (2001: 81 ss.): Ortiz acaba de entrevistarse con Godoy en Aranjuez, y éste le ha animado a continuar el viaje, aunque sabe igualmente que los medios económicos no van a ser muchos. En abril de este año se dirige a Pedro Cevallos Guerra -Secretario de Estado de 1800 a 1808, pero primo político y alter ego de Godoy-, acompañándole el dictamen que acababa de hacer sobre las antigüedades halladas cerca de Osuna y ofreciéndose para excavar allí, si el rey decide que se continúen dichos trabajos. Le enviará copia además, dice, de otro informe que le encargó la Academia sobre el precioso pavimento mosaico hallado en Itálica (el del Circo y las Musas) «...que se está perdiendo miserablemente...». Le aclara que ambos trabajos pertenecen al plan de su Viage, como la memoria sobre el teatro saguntino porque, añade con legítimo orgullo, «...gracias a Dios, para todo tengo ánimo, fuerzas y genio...».

Buscando soluciones de financiación, Ortiz recibe, y traslada a Cevallos, una noticia «de la ciudad de Sanfelipe mi patria»: el deán de Játiva, D. Félix Mollá, de ya 90 años, «estaba el día 14 sin esperanza de $v i d a \gg . .$. Si falleciera en ese mes, el rey podría sugerir al arzobispo de Valencia el nombramiento de Ortiz para sucederle; así «...lograríamos la prebenda y con ello los fundos para proseguir mi viaje anticuario. Su valor anual es de hasta 4000 ducados, y lo sé por ser mi iglesia, y haber sido en ella cura párroco por más de cuatro años, de donde me sacó el Rey para mi viaje de Roma...» ${ }^{14}$. Cevallos escribe ese mismo día, el 23 de junio de 1802, al arzobispo, ignorando que el deán Mollá ya había fallecido y recomendando a Ortiz. Y, en efecto, nuestro vicario arqueólogo es propuesto, y nombrado el 12 de octubre siguiente, para el deanato de Játiva.

Aunque permanecerá dos años más en Madrid, su vida se va a enfocar ya definitivamente hacia Játiva y Valencia. En 1804 ingresa como académico en la Real de San Carlos valenciana, donde, casi medio siglo atrás, había iniciado sus primeros estudios de Dibujo arquitectónico. Su Oración sobre las Nobles Artes, compuesta para esta ocasión y publicada en las Actas de la sesión, es una apasionada defensa del clasicismo grecorromano (Goberna 1988: 87). En 1807 sale por fin su libro de Sagunto, con cuyo motivo hace su última visita a la capital, pues en marzo siguiente cuaja la crisis con Francia y sobrevienen la entrada de las tropas napoleónicas y las operaciones militares, que pronto se extienden a casi toda la Península. A fines de 1807 o comienzos de 1808 tiene ocasión el deán, en unión de su paisano y amigo el también famoso Joaquín Lorenzo Villanueva, de practicar unas breves excavaciones junto a la iglesia de San Felipe de Játiva, buscando los restos de la primitiva iglesia goda, y en las que encontraron muchos pedestales, capiteles y otras piedras labradas. Volvieron a enterrar lo hallado (quizá esté aún allí), pensando presentar a la Academia de la Historia un plan más completo de exploraciones, pero la guerra lo impidió (Goberna 1998: 82).

En 1812, aunque ocupadas por los franceses desde enero Valencia y Játiva, Ortiz continúa atendiendo a sus obligaciones religiosas y ciudadanas, y aprovecha para contestar y publicar su respuesta a la dura crítica de él publicada por E. Palos y Navarro, juez conservador por S.M. de las antigüedades saguntinas (otro elogiable precedente, debido también al tan injustamente denostado Carlos IV). El 25 de julio de 1813

14. Obsérvese que esto, escrito de su mano, presenta cierta contradicción con lo que por el mismo expediente, y por el relato de su sobrino, sabemos ( $c f$. supra); quizá adelantó su vinculación con Carlos III para mejor tener la concesión. 
preside el solemne tedeum durante el cual se jura en público la Constitución de Cádiz. Pero en mayo de 1814 Fernando VII vuelve a Madrid y comienza la represión de los simpatizantes liberales.

Con ocasionales recaídas de salud, se dedica en los siguientes años a escribir sus Instituciones, terminadas en 1818, y una edición, comentada asimismo en latín, de Vitruvio, que quedará inédita. Se incorpora decididamente a la vida institucional de la Iglesia Colegial de Játiva, cuyas obras de restauración había supervisado durante muchos años atrás. Poco a poco va abandonando sus funciones canónicas, razón por la cual llega a recibir en 1816 (a sus casi ochenta años) un apercibimiento del capítulo colegial (Goberna 1998: 86). Quizá gracias a ello, publica en ese mismo año, del griego y con propósitos didácticos, el Manual de Epicteto o Enchyridion (1816), y al siguiente su pequeño estudio sobre la legión XII Fulminante (1817), y no dejó de asistir en Valencia, mientras pudo, y como también había hecho en Madrid, a tertulias literarias y de bibliófilos.

Cosa realmente infrecuente en un clérigo de su época -como dije, quizá debido a su formación con los jesuitas y a la visión cosmopolita de la que se impregnó en los años de Roma- D. José Ortiz fue un liberal de mentalidad y de ideología, y estuvo propuesto por los diputados valencianos para consejero del Reino en las Cortes de Cádiz. En consecuencia, sufrió diversas censuras con la vuelta absolutista de Fernando VII (Goberna 1998: 88). La Real Audiencia de Valencia no da el pase a una carta de réplica a propósito de un epígrafe romano valentino, que sólo consigue publicar durante el Trienio liberal, y ya convertida en libro (Ortiz 1820), donde trata cuestiones de interés acerca de la siempre debatida fundación de Valencia (Goberna, ibid.). Publica también entonces, durante el Trienio (a cuya Junta Suprema de Valencia perteneció), una «oda sáfica» al regreso de la Constitución liberal.

En 1816, ya con setenta y siete años, se había trasladado a vivir de Játiva a Valencia, por su salud y para auxiliar el desamparo en que había quedado su sobrina Josefa Ortiz y sus numerosos hijos a raíz de la muerte de su marido, el gran grabador López Enguídanos. Allí pasará, siempre activo, los últimos seis años de su vida, aunque las recaídas son cada vez más frecuentes. No poco debió de empeorarle la noticia, en agosto de 1822, de una deuda por sus medias annatas o impuestos, que era legalmente discutible pero condujo a retenerle sus salarios. El día antes de su muerte aún dicta a uno de sus sobrinos una alegación, que tendrá éxito, pero sólo temporal.

En la mañana del 21 de diciembre de 1822, camino de cumplir los 84 años, D. José Ortiz y Sanz, uno de nuestros más preclaros anticuarios, arqueólogos y teóricos de la Ilustración, un hombre de asombrosa vitalidad y producción, fallece en Valencia, donde fue enterrado. Las consecuencias de la represión antiliberal, al fin del Trienio, se prolongaron contra su obra y su familia, incluso después de su fallecimiento: al regreso de Fernando VII, la deuda que las Cortes le iban a condonar en atención a sus méritos literarios no sólo se cargó entera a sus herederos, lo que les obligó a vender la mayor parte de la biblioteca del fallecido anticuario, sino que hasta 1841 , muerto ya este despótico rey, fueron inútiles sus esfuerzos para publicar las diversas obras que su tío había dejado manuscritas, a algunas de las cuales al principio me referí, y que hubieron de esperar más de veinte años para ver la luz.

Hecha esta breve semblanza, conviene ahora que leamos ya, de la propia mano de Fray José Ortiz, cómo debía plantearse a su juicio una catalogación de los más importantes yacimientos romanos de España (y no estará de más que recuerde que, en el año 2002, todavía no la tenemos hecha en cuanto tal ${ }^{15}$ ), qué ramos del saber arqueológico debían de ser tenidos en cuenta y a qué fin servía cada uno de ellos y, por fin, su listado de las ciudades y parajes, esto es, yacimientos urbanos y rurales, que en su época presentaban obras dignas de consideración y estudio, y que es, sin duda, la parte que mayor interés puede tener aún para los catálogos e investigaciones de nuestros días.

15. Lo más parecido a ello, incluyendo los requisitos de calidad, de que disponemos, no es obra española, șino alemana: El volumen de la serie Hispania Antiqua, del Instituto Arqueológico Alemán de Madrid, dedicado a la Hispania romana (VV.AA. 1993). 


\section{TRANSCRIPCIÓN LITERAL DEL PROYECTO DE VIAJE ARQUEOLÓGICO DE J. ORTIZ}

Paso ahora a transcribir enteramente el pequeño folleto en el que Ortiz detalló su ambicioso Viage-nunca llevado a efecto-, y ello a partir del ejemplar que se conserva en el Archivo Histórico Nacional de Madrid, signatura de la sección de Estado, leg. 3244. De esta obrita en nuestros tiempos sólo se han reproducido algunos párrafos (Matilla 1997: 42-44), y existe sólo una reedición valenciana, poco manejable por ser en microforma (Ortiz 1797b). En todo caso, y hasta donde sé, no se ha puesto nunca de relieve lo que este programa de trabajo puede tener de útil y concreto, algo más de dos siglos después, para nuestra Arqueología práctica.

Haré algunas advertencias previas: El texto se publicó, como es natural, con la ortografía del momento; pero he preferido adaptarla a la actual, por creer que no afecta en nada a su contenido y en cambio hace más cómoda su lectura. Los principales usos de Ortiz (corrientes en todo caso, como digo), afectan a: empleo de $\mathrm{g}$ por $\mathrm{j}$ (extrangeros, viages...), de x por $\mathrm{j}$ (dexa, dibuxadas, execución), de q por c (antiquario, quando); escasez de acentuación, sobre todo para romper diptongos (paises), pero, en cambio, uso de tildes en monosílabos como á,ó, ú, fué; de acento circunflejo ocasional (exâcto, auxîlios), etc. He mantenido, sin embargo, su puntuación entre frases y párrafos, así como la grafía de todos los términos que él escribe con mayúsculas (profesiones, autoridades, étnicos y gentilicios) y los nombres propios y de lugares, aunque hoy sean erróneos (Guadalquibir, Tíboli, Proenza...), señalándolos para que no se tomen por erratas de transcripción. En algunas muy contadas ocasiones suplo alguna palabra entre <--->, y escribo correctamente palabras como colunas o inumerables, también propias de su época. Como su texto tiene muy pocas notas a pie, he optado por incluirlas entre las mías propias, debidamente advertidas y con el texto en cursiva, con objeto de no generar aquí dos clases de notas. Al llegar al Itinerario arqueológico propiamente, incluyo en las notas a pie el seguido por el Voyage Pittoresque de A de Laborde, a efectos de comparar ambos.

\section{NOTICIA Y PLAN DE UN VIAGE ARQUITECTÓNICO-ANTIQUARIO, encargado por S. M. a Don Joseph Francisco Ortiz el año de 1790}

Un Viaje Arquitectónico-Anticuario por las provincias de España es tan importante como deseado de los Artistas y Literatos. Insufribles son, aunque por desgracia no muy infundadas, las acusaciones de los extranjeros sobre nuestra indolencia respecto a las antigüedades que tenemos enterradas. Acúsannos de que ninguna diligencia practicamos en busca y descubrimiento de monumentos antiguos que podrían ilustrar las Artes, la Geografía, la Numismática, la Lapidaria, la Historia y otras facultades y ciencias, al paso que enriquecerían los museos de inestimables tesoros. Los Españoles, dice un Italiano de nuestros días, y con él otros viajeros Ingleses, Franceses, etc., los Españoles no saben aún lo que llevan entre los pies, ni conocen el precio de las antigüedades.

Confesamos con dolor la verdad de la primera parte de su dicho; pero la segunda es una calumnia manifiesta. Los extranjeros que así pronuncian de todos los Españoles son por lo común unos viandantes sin ciencia ni prudencia, venidos más bien a tunar, que a tomar exacto conocimiento de España. Léanse los Viajes de Clark, Caimó, Figaró, Swimburne [sic], las Cartas Judaycas del impío Argens, las de Coste, las Persianas, y de otros de este siglo, y apenas se hallará noticia que no claudique por una u otra parte, en medio de innumerables imposturas, invectivas y aun vaciedades, copiadas de librotes viejos tan despreciables como los suyos. ¿Y qué otra cosa pueden producir unos forasteros errantes, que sin saber caminos, lenguas ni genio de los países, y careciendo de innumerables datos de absoluta necesidad, corren toda la península en diez o doce meses, cuando para hacerlo como debían se necesitan otros tantos años? Si aún los que viajan detenidamente por sus mismos países suelen equivocarse no pocas veces en cosas propias, ¿qué podremos esperar de los que discurren por los extraños con tanta precipitación y ligereza? 
Los Españoles doctos Ocampo, Morales, Nebrixa, Núñez, Resende, Vives, Agustín, Mariana, Chacón, Llanzól de Romaní, Roa, Caro, Ustarroz, Palmireno, Mondéjar, Antonio, Martí, Mayans, Florez, Velazquez, Bayer, Lumiares y otros sin número, han sabido, no menos que los extranjeros eruditos, el aprecio que se merecen los monumentos antiguos, por lo mucho que sufragan a toda buena literatura. Mas para descubrirlos, ilustrarlos y publicarlos, se requieren personas no sólo versadas en este género de letras, sino también dotadas de genio y constancia: se requieren años: se requieren no pocos caudales. ¿Son acaso fáciles de juntar estos extremos? Don Manuel Martí, Deán de Alicante, bien conocido en la república de las letras, escribía al sabio Inglés John Conduith, que viajaba por España a principios de este siglo ${ }^{16}$, en los términos siguientes: También yo quise en otro tiempo ilustrar las cosas de la patria; pero frustró mis anhelos el hado enemigo de España. Mis facultades ${ }^{17}$ son ningunas, las de los amigos, tenues; las de los señores están ociosas, y ahora por la malignidad de los tiempos, consumidas. La deseada empresa no deja de ser costosa. ¿Con qué socorros pues recorreré la España? ¿visitaré las ruinas antiguas? ¿revolveré las cenizas abandonadas? ¡Diréis que con las del Soberano! Ese solo recurso me queda; y quizá lo conseguiría de mi óptimo Príncipe, si hubiera quien solicitara sus auspicios, etc. ${ }^{18}$.

Con las mismas expresiones se conduele en otras cartas al verse sin medios, sin auxilios, y aún sin esperanzas de poder poner en planta su noble deseo. No le proporcionó la suerte otros desahogo, que enviar al sabio Montfaucon algunos diseños, inscripciones, monedas, \&c., a fin de que les diese lugar en su famosa obra de L'antiquité expliquée. Quejábase este docto Benedictino, diciendo: En balde he solicitado hasta ahora hallar muchas cosas pertenecientes a los antiguos Españoles; a saber, la forma ofigura de su Dios Endovélico, el hábito de los Españoles antiguos y el de su tropa de caballería. De las otras naciones tengo uno y otro; mas no de la Española. El de su infantería lo sabemos por el escudo de Scipion, hallado en Leon ${ }^{19}$ de Francia, y publicado por Jacobo Spon. Si tenéis a mano, varón esclarecido, algunas de estas cosas, haréisme señalada merced en comunicármelas \&c. ${ }^{20}$.

En efecto, le envió Martí diseños del anfiteatro de Itálica (que pocos años antes había sido casi aniquilado para con los materiales construir un dique en el Guadalquivir), del teatro de Sagunto, de la quilla y parte del casco de una nave antigua, hallada por entonces limpiando el puerto de Cartagena, de algunos relieves, lucernas, figuras, medallas, \&c.: pero las más de estas cosas parece que se perdieron en el camino, o Montfaucon las suprimió por ir mal dibujadas. Únicamente publicó en la segunda parte del tomo III, una vista del teatro de Sagunto, y la planta del anfiteatro de Itálica, una y otra diseñadas sin inteligencia; y ésta debió de ser la causa por que Montfaucon se resistía a publicarlas como se las enviaban ${ }^{21}$.

16. Véase, p.ej., «A Dissertation upon the antient Carteia» (sic), en las Philos. Trans. del año 1719, por John Conduit Esq. F.R.S (Canto, e.e.).

17. Nota de Ortiz, en pág. 5: Et ego quondam ad illustrandas res patrias \& spem \& animos erexi. Sed fregit acrem illum impetum malus quidan Hispaniae Genius. Facultates enim nostrae nullae: anicorum copiae exiguae: procerum opes inertes, eaeque temporum acerbitate attritae. Est enim res sumptuosa quam parabamus. Quo igitur viatico Hispaniam omnem peragrabo? antiqua lustrabo rudera? neglectos versabo cineres? Nempe regio. Id unum superest. Fortasse id impetraremus ab optimo Principe si essent qui ejus auspicia sollicitarent \&c. Lib. VII Epist. 11. «Facultades», al principio de la cita, está, obviamente, por «riquezas, fortuna», como se ve de las dos frases siguientes, donde omite las palabras copiae (amicorum) y opes (procerum), que dan perfectamente el mismo sentido.

18. Ubica el texto latino que está traduciendo como nota final, 1, de la pág. 5 .

19. Lyon, la antigua Lugdunum.

20. Nota de Ortiz, en p. 6: Multa quae ad veteres Hispanos pertinent, hactenus frustra quaesivi, nempe quae fuerit forma Dei Endovellici, qui veterum Hispanorum vestitus, qui equitum Hispanorum apparatus. Caeterarum nationum \& vestes \& equitatum habeo: Hispaniae minime. Militarem solum peditum Hispanorum cultum habemus in scuto Scipionis Lugduni reperto, \& a Jacopo Sponio publicato. Si quae hujusmodi ad manum habeas, perquam gratissimum, vir clarissime, facies, si mecum communicaveris $\& c$. Lib. VIII Epist. 2.

21. Nota de Ortiz, en pág. 7: Véase su carta a Martí entre las de éste, Lib. VIII Epist. 4, y las 9, 11, 14, \&c.. 
La Academia de Buenas Letras de Sevilla, el Maestro Fray Enrique Florez, los historiadores de algunas ciudades y pueblos en particular, y algunos otros sabios, han dado también al público varios restos antiguos. Pero el modo con que los han producido está tan lejos de satisfacer el gusto y deseo de los Artistas, en especial Arquitectos, que más presto les han aumentado las ansias de verlos dibujados y medidos artísticamente y con inteligencia de partes. Fuera de que estos escritores no han publicado sino una muy pequeña parte de lo que nos queda.

Quedan pues enterrados en España innumerables monumentos, no porque ignoremos el aprecio que se les debe, sino por otras causas muy diversas, independientes de nuestra voluntad, y no peculiares de nuestra nación. Digan los Romanos ${ }^{22}$, ¿por qué causa tienen alquilada para inmundo estercolero la más entera porción del anfiteatro Flavio, en cuyos pórticos hay de continuo millares de carros de estiércol hasta junto a las bóvedas, causándolas notable perjuicio la putrefacción y salitres? ¿Por qué causa están sirviendo de heniles las termas de Caracala, la casa áurea de Nerón, y otros preciosos monumentos? ¿Por qué son tiendas, tabernas y bodegones los pórticos exteriores del teatro de Marcelo, y su orquesta, gradas y demás partes convertidas en un feísimo palacio? ¿Por qué se emplean en tiendas de vidriado los arcos menores del triunfal de Septimio Severo, cuyos inquilinos destruyen de mil maneras sus hermosos ornatos? Por qué razón es corral y corro de búfalos el mausoleo de Augusto, junto a Ripetta? ¿Qué templo antiguo, qué circo, qué sepulcro, qué venerable monumento queda en la campaña de Roma, que no sea miserable despojo de la barbarie aún presente, y hedionda zahúrda de toda suerte de ganado? ¿No se mantiene hecha un caos de ruinas y maleza la famosa Vila Adriana en Tíboli $[$ sic $]$ ? ¿Nimes de Proenza ${ }^{23}$, no tiene su maravilloso anfiteatro lleno de un desdichado caserío en que habita mucha parte del bajo pueblo ${ }^{24}$ Acaso estuvieran aún enterradas las antiguas ciudades de Herculano, Pompeya y Stabia en la falda del monte Soma o Vesuvio, si no las hubiera descubierto en parte nuestro gran Carlos III siendo Rey de Nápoles. Así lo persuade lo poco que se ha continuado su descubrimiento, pudiéndose contar por nada respecto a lo que el Rey Carlos dejó descubierto. Perdiéndose están entre matorrales, y sirviendo de boyeras o pocilgas los famosísimos templos Dóricos de Pesto o Posidonia. Ni tienen mejor destino las antiguiedades de Pozzuolo y Bayas, con otras innumerables que omito. ¿Será la causa de su abandono el poco aprecio que hagan de ellas Italianos y Franceses?

De ningún modo. Las aprecian debidamente; pero no siempre se pueden cumplir los votos de los sabios. Cuando parece hay la mejor proporción para lograrlo, se atraviesan estorbos que frustran o difieren para otro tiempo las empresas. Esto puntualmente ha sucedido también ahora en nuestras antigüedades en especial Arquitectónicas. El Señor Don Carlos III, bien persuadido de la utilidad de un viaje dirigido a los objetos arriba dichos, me lo mandó emprender de cuenta de su Real Erario el año de 1788, autorizando mi persona, y auxiliando mi comisión por todos modos ${ }^{25}$. Púseme en camino según la ruta que doy abajo, a mediado Agosto del mismo año: pero a 50 leguas de $\mathrm{Madrid}^{26}$ tuve el infortunio de caer en una enfermedad tan grave y porfiada, que con mucha dificultad y trabajo pude recobrar mi salud al cabo de dos años.

22. Esto es: los ciudadanos modernos de Roma. Comienza así una diatriba sobre el estado de abandono en que también se encontraban en su tiempo muchos monumentos insignes de la propia capital del Imperio (y de la Arqueología europea), en la que él había vivido y que conocía bien, así como de algunos otros puntos notabilísimos de Italia (Tivoli, zona de Nápoles, Sicilia griega, Pozzuoli, Baiae, etc.), que obviamente conocía de visu. Su objeto es, evidentemente, probar que los españoles al menos no despreciaban sus monumentos más que los propios italianos los suyos, pero que, en todo caso, como dirá más adelante, ello no se debía a una falta de estima de los eruditos respectivos, sino a circunstancias ante las que todos ellos, españoles, italianos y franceses, se sentían igualmente impotentes.

23. Sic. Nîmes, en la Provenza gala.

24. Nota de Ortiz, en pág. 10: He oído decir que el Gobierno Francés ha mandado se quiten las tales casas, y<se $>$ limpie la arena.

25. Carlos III falleció el 14 de diciembre de ese mismo año. Hay una contradicción en esto ( $c f$. infra).

26. En Játiva, vid. supra. 
En este medio tiempo, ascendido al trono el Señor Don Carlos IV, e informado del estado de mi salud y viaje, tuvo a bien ordenarme que le continuase para primavera de $1791^{27}$; pero también esta vez hubo de suspenderse por nuevos cuidados ocurridos en el Ministerio, y por las guerras sobrevenidas, aún no bien terminadas ${ }^{28}$. No habiéndose pues efectuado la empresa, ni aun en parte, me ha parecido conveniente comunicar al público sus objetos y plan, a fin de enterarle de las utilidades que resultarán cuando se lleve al fin esperado.

\section{Objeto del viaje en sus varios ramos}

\section{ARQUITECTURA}

Se han de tomar geométricamente las plantas y alzados de todos los edificios antiguos Griegos o Romanos que quedan esparcidos en varios parajes de España, enteros o en ruinas, v.gr. termas o baños, arcos, templos, naumaquias, circos, teatros, anfiteatros, puentes, acueductos, caminos, calzadas, sepulcros, \&c. De todos se ha de hacer crítica rigurosa y fundada de lo que fueron, en qué tiempo, y por qué gentes se edificaron, según ofrezca el estilo formal y material que las naciones usaron en sus obras Arquitectónicas. Observaráse la cantidad y calidad de los materiales que empleaban: la varia combinación o colocación de ellos: las dimensiones de los sillares, y demás circunstancias que presenten y puedan ser útiles para la entera restauración del arte de edificar. En todos los monumentos considerables no íntegros se suplirá la parte derruída ${ }^{29}$, por la guía de lo que reste, distinguiéndolo en los diseños. Lo mismo se hará de uno a otro edificio Gótico, Árabe y aun posterior, que tenga alguna recomendación o circunstancia notable, y que pueda prestar luz a la Arquitectura, Historia, Anticuaria, \&c. Para la exactitud de las medidas se harán las excavaciones y desmontes oportunos hasta descubrir los pavimentos o suelos, de manera que puedan tomarse bien las anchuras, longitudes y altura de las piezas, paredes y miembros. De los arquitectónicos que se encuentren, v.g. basas, columnas, capiteles, cornisas, ornatos, molduras, \&c., se escogerán los mejores en ejecución y materia de cualquiera Orden que sean, y se conducirán a S. M., a fin de que siendo de su Real aprobación, se coloquen por orden y clases en la Real Academia de San Fernando, donde puedan los Arquitectos estudiar el Arte sin ir a Roma. Hace muchos años que hallándose en aquella capital del mundo el autor de este viaje, formó el ventajoso proyecto de vaciar en yeso un suficiente número de los referidos miembros, con deseo de que nuestra nación fuese la primera que tuviese colección o museo Arquitectónico de vaciados, no pudiendo de pronto poseer originales. Pero no se logró su deseo.

\section{ESCULTURA}

En las excavaciones de ruinas antiguas de edificios Griegos o Romanos, es ordinario hallarse relieves medios y bajos, estatuas, medallones, candelabros, jarrones, rosetones, y otras obras de jaspe, mármol, bronce, y aun de los metales preciosos. Por ellas venimos en conocimiento de las antigüedades gentílicas,

27. Estos años de 1791 a 1793 ven múltiples actividades de Carlos IV en favor del estudio y protección de las antiguiedades españolas. De ellas trato en mi reciente monografía, incluyendo las referencias a este fallido viaje de Ortiz. En ese mismo verano de 1791, por ejemplo, es cuando se encomendó la misión arqueológica de Mérida al hispano-portugués Manuel de Villena Moziño; y en 1792 se crearía la Sala de Antigüedades de la Real Academia de la Historia (Canto 200 la: 34-44, 48-49 y passim).

28. Se refiere sin duda a la Secretaría de Estado, que ocupaba desde fines de 1792 Manuel Godoy y Álvarez de Faria, el joven amigo y colaborador de Carlos IV. Ya habían comenzado a agudizarse los conflictos y los enfrentamientos militares con la emergente nueva república francesa. Parece un indicio de que está escribiendo estos párrafos en torno a 1795, antes de firmarse la célebre Paz de Basilea.

29. Escrito diruida. 
de las deidades, ritos, vestidos y usos de nuestros antepasados en paz y guerra: la forma de las armas y armaduras, el calzado, los arneses de los caballos, y variedad de instrumentos, cuya noticia es útil y curiosa. Hállanse también camafeos grabados, instrumentos de sacrificios y de música, páteras, cuchillos, lituos, sistros, \&c. Aún se suelen hallar triclinios, lectisternios, nupcias, y otras funciones gentílicas expresadas en bajos relieves, que sirven para la inteligencia de la historia antigua. Tres o cuatro relojes solares de horas desiguales, abiertos en mármol, se hallaron a mediado este siglo en varias excavaciones de la campaña de Roma. Ninguno tenía gnomon, aunque se veía haberle tenido. El célebre padre Boscovich restauró uno de ellos, y está señalando las horas en una ventana del museo Capitolino: los otros fueron también rehabilitados por otros sabios. No sería en España tan abundante como en la capital del Imperio Romano la mies de estas curiosidades; pero de las halladas en varias ocasiones sin buscarse de propósito, inferimos sería grande. Muchos testigos de vista tenemos de que en Mérida, Sagunto, Clunia, Andujar, Caparra y otras partes, apenas se zanja la tierra para cosa alguna sin hallarse estatuas, relieves, inscripciones, medallas, miembros arquitectónicos, sepulcros y otras mil cosas apreciables.

\section{MOSAICOS}

Los Mosaicos pueden no menos ilustrar la Historia, la Mitología, y las nobles Artes. Sean ejemplo los de las antiguas basílicas de Roma, explicados por Ciampini, y otros Anticuarios doctos. Y en España los de Barcelona, Rielves, Jumilla, Valencia, y otros que permanecen en despoblado, sufriendo los descalabros e inclemencias de las estaciones.

\section{MEDALLAS $^{30}$}

La costa meridional y oriental de España desde el Cabo de S. Vicente hasta Cataluña, está rica de medallas Fenicias, Cartaginesas, Griegas, Romanas, Árabes y Españolas antiguas, llamadas desconocidas por no haberse hasta ahora podido leer ni conocer sus letras o caracteres, aunque lo han tentado algunos. En las provincias mediterráneas ${ }^{31}$ se hallan también muchas; pero menos que en las marítimas. Las medallas conocidas y de buena nota son documentos auténticos y seguros para la Historia, Cronología, Geografía y recta pronunciación de los pueblos y municipios que las batieron. Sería por demás querer persuadir aquí la grande utilidad de las medallas, una vez reducidas a series cronológicas de Cónsules, Emperadores, Reyes, Magistrados, Sacerdotes, \&c. Bastante la acredita la suma diligencia que los Monarcas, Señores, y aun personas de menor grado han puesto y ponen en recogerlas a cualquiera precio, y coordinarlas en sus monetarios.

\section{INSCRIPCIONES}

En España pocas veces o nunca se han buscado de propósito las lápidas o inscripciones ${ }^{32}$. Las que tenemos, que son en gran número, se deben al acaso de cavar, arar, o abrir algunas zanjas. A la casualidad debemos también las pocas antigüedades hasta ahora descubiertas, como lo prueban las de Cabeza del Griego, Toledo, y otras encontradas estos años, en las cuales se ven urnas sepulcrales, lápidas, bases y otros monumentos

30. Las llama indistintamente monedas y medallas.

31. Está en el puro sentido latino: «interiores».

32. Se refiere a rebuscas y excavaciones, no a la recolección científica, en la que, treinta años atrás, el ya citado marqués de Valdeflores había realizado una labor titánica, recopilando él solo más de cuatro mil inscripciones. Aunque sus trabajos quedaron inéditos, esa labor tenía que ser de conocimiento de los expertos, además de que, en 1796, sus manuscritos acababan de llegar desde Málaga a la Real Academia de la Historia (Canto 1994: 513-514), y es muy posible que el P. Ortiz por lo menos tuviera noticia de ello cuando da a la imprenta el texto de su proyecto. 
apreciables. Las inscripciones legítimas son uno de los lugares ${ }^{33}$ históricos más estimados y seguros. Enséñannos los ritos gentílicos (y aun cristianos): nos dan noticia de los Sacerdotes, Flámines, Arúspices o Agoreros, Pontífices, y otros Ministros de la superstición: de los Magistrados: de sus honores y dignidades. De las deidades a quienes se dedicaban sus aras, bases y simulacros ${ }^{34}$. De las legiones, de sus jefes, y de muchos de sus soldados. De los votos y donativos a los Dioses. De las dedicaciones de sus estatuas, templos y $\operatorname{lucos}^{35}$, con otras muchas noticias útiles a la Historia política y civil de los pueblos antiguos. En mármoles se han hallado los más apreciables fastos Consulares, calendarios, leyes agrarias, edificatorias, federales o sociales, senatusconsultos, decretos militares, \&c.; de manera que sin las inscripciones ignoraríamos lo mejor de la antigüedad. Para convencerse de esto, léase el cuerpo Gruteriano ${ }^{36}$, o las colecciones de Fabretti, Muratori y otras, donde se verá son innumerables los conocimientos que las inscripciones ofrecen. Si no se hallase en algunas de ellas el pie y palmo Romano antiguo, nunca hubiera podido saberse su medida, por otra parte tan necesaria. ¿Cuánto nos han disputado los críticos la legitimidad de algunas inscripciones de los Emperadores Nerón, Diocleciano y otras que tanto honor hacen a los Cristianos de España en los primeros tiempos y persecuciones de la Iglesia? Si se practicasen las excavaciones donde conviniese, sin duda hallaríamos otras inscripciones que disiparían las dudas, e ilustrarían mucho los artículos indicados. Por ellas se rectificarían los nombres de ciudades, pueblos y municipios que le tienen alterado, equivocado o dudoso. Se podría conjeturar el paraje en que estuvieron los pueblos en ellas nombrados, por el en que se hallarían las piedras ${ }^{37}:$ siendo cosa natural no estuviesen lejos de ellas, mayormente si fueren muy grandes las bases, $\operatorname{cipos}^{38}$ o lápidas, y difíciles de ser trasladadas.

\section{GEOGRAFÍA $^{39}$}

Por las inscripciones y medallas podríamos venir en conocimiento de muchos pueblos antiguos de España, cuyo paraje se ignora o se duda. De un gran número de ellos no nos queda más noticia que el nombre, y ése desfigurado e incierto, por la variedad de lecciones en los códices de los escritores. Aun de provincias enteras ignoramos la situación y mucho más los límites. De Numancia, Munda, Astapa y otras ciudades celebérrimas en la antigüedad por su extraordinario valor, sólo nos han quedado la fama y el nombre por ser inmortales: del sitio donde estuvieron no tenemos cosa decidida, quizá por no haberlo buscado donde nos encaminan los autores. Demos una leve muestra de pueblos antiguos, cuya situación se ignora o no se sabe con certeza ${ }^{40}$. Los que leen nuestras historias eclesiástica y profana preguntan dónde estaban ${ }^{41}$

33. En el sentido de «fuentes».

34. Traduce directamente del latín simulacra, «estatuas, imágenes», aunque tal acepción está ya en desuso hoy en día en el español.

35. Esta palabra ya no se encuentra en los diccionarios actuales de español, pero sí lo estaba, hasta mediados del siglo XX, como equivalente parcial del lucus latino.

36. Traducido literalmente de «corpus», el término clásico para las colecciones epigráficas.

37. Sic. Está por «a partir de aquél en el que se hallaran...».

38. Escrito cippos. Este argumento lógico sigue siendo válido, aunque cada vez menos.

39. Se refiere, naturalmente, a la Geografía Antigua o Histórica.

40. Comienza aquí una larga lista de 131 ciudades y un pueblo antiguo sobre los que no existía seguridad de ubicación (aunque, tras la mención de los Olcades, se ciñe sólo a ciudades). En esta relación, curiosamente, Ortiz utiliza todavía el sistema romano de ordenación alfabética, esto es, sólo por la letra inicial. La he copiado al pie de la letra, de modo que los errores han de deberse a las lecturas más corrientes en su época (muchas dudosas, como él mismo dirá a continuación), o bien son propios de Ortiz. Tal ocurre con Arbócola por Albocela, Anitorgis, que debe de estar por Amtorgis, Alpesa por Salpensa, Beleya por Veleia, Besula por Paesula, Eliocrota por Eliocroca, Sepelacia por Sebelacia y así sucesivamente. En otras, o hay un error real (Libisocia por Libisosa, Tela por Gela, ¿Cannela por Carmona, Tituleya por Titulcia?), o bien me es imposible reconocer hoy la ciudad a la que se refiere (Tubucci, Trigundo).

41. Por falta de espacio no me puedo detener a comentar las localizaciones de éstas que han sido aclaradas en estos dos últimos siglos. Pero, en atención al lector, he destacado en negritas en la lista de Ortiz aquéllas -nada menos que 77-que en estos dos 
Arbócola, Altea Metrópoli de los Olcades, los Olcades mismos tan nombrados en las guerras de Aníbal, Alces, Anitorgis, Asena, Alona, Aspavia, Atanagia, Ategua, Arcóbriga, Acinipo, Alontigi, Alpesa, Aria, Arsa, Arua, Abdera, Axati, Artigi, Asido, Acatucci, Atubi, Andura, Aratispi, Bigerra, Bardon, Besippo, Basilippo, Balsa, Beleya, Barbesula, Barbariana, Besula, Barca, Belon, Bigastro, Cápara (si acaso no es el despoblado de Caparra en la Vera de Plasencia, donde son admirables las antigüedades Romanas que aún duran, y nombra nuestro Juan de Arfe), Carmela, Cardon, Cartago-vieja, Contrebia, Cárula, Catóbriga, Caravi, Consabro, Corbion, Cisa o Stissa, Carteya, Cunistorgis, Carissa, Calento, Claritas-Julia, Deobriga, Deobrígula, Dipon, Décuma, Ebura, Ergavica, Erisana, Epora, Equabona, Elotana, Eliocrota, Graccurris, Hactana, Hibera, Hippona, Holona, Heraclea, Ipagro, Ilipa, Ilipla, Ilipula, Intercacia, Ilduno, Intibilis, Iliturgi, Itucci, Ibila, Langobriga, Lancia, Laurona, Litabro, Lutia, Lacipea, Leuciana, Libisocia, Lastigi, Lepia, Lelia, Malia, Murgi, Menoba, Mergablo, Mundobriga, Melaria, Nertobriga, Nescania, Ocile, Olontigi, Oreto, Oxtraca, Saguncia, Segeda, Segisama, Silpia, Salacia, Scalabis, Sepelacia, Sisapo, Salduba en la Bética y, por consiguiente, diversa de Zaragoza, Sacili, Salambina, Talabriga, Termesta, Tricio, Tribola, Turbola, Tucia, Tituleya, Turissa, Tubucci, Trigundo, Tela, Ugia, Urbiaca, Uttari, Valeponga, Vélica, Vallata junto a Astorga, y por consiguiente diversa de Vallada en el Reyno de Valencia, Vindeleya, con otros pueblos y municipios que nombran Polibio, Diodoro, Livio, Cesar, Mela, Estrabon, Plinio, Silio, Dion Casio, Antonio Pio, Tolomeo, Estéfano, Vibio, Justino y otros escritores, como también nuestros Concilios, historias, y códigos legales.

Ciertamente de muy pocas de estas poblaciones podemos dar noticia que pase del nombre, y aun éste casi siempre vario y disputable, por escasez de inscripciones o medallas que lo fijen. Por todas las provincias de España, singularmente en Extremadura y las Andalucías, ven con disgusto los viajantes a cada paso poblaciones antiguas muy grandes medio sepultadas en sus ruinas, esperando una mano benéfica que las desentierre y saque de las tinieblas. Sin esta diligencia (por otra parte no poco difícil y costosa) ¿cómo podremos aprovecharnos de ellas? ¿Cómo saber a qué nación y tiempo pertenecen? Aun con los auxilios para el empeño, no siempre están a mano sujetos idóneos que no malgasten años y caudales ${ }^{42}$ : que quieran dejar el reposo de sus hogares, y emprender cuidados y viajes tan penosos, en que faltan cuantas comodidades se gozan en casa propia. ¿Es acaso negocio accesible y agradable a todos desmontar ruinas, descubrir suelos, subir sobre los acueductos, paredones y demás monumentos, hacer indagaciones, tomar medidas, levantar planos, perfiles y vistas, combinar partes, averiguar proporciones, dibujar cuanto convenga, sacar partido de cada miembro, de cada moldura; con otras muchas cosas que las circunstancias aconsejen? Sabemos cuán empeñado estuvo el Ministerio seis años hace en averiguar el verdadero paraje en que estuvo la célebre Munda; pero quiso la suerte se encargase del negocio a cierto Ingeniero ${ }^{43}$ que carecía de todos los datos y conocimientos indispensables para ello. Después de haber dado que reír a los literatos el modo con que pensó hallar a Munda, y de haber malgastado dos años y no poco dinero sin adelantar un paso, se le hubo de mandar lo dejase.

En suma, nuestra Geografía antigua yace todavía sepultada en sí misma, y lo estará hasta que la socorran los influjos del solio, que son los únicos que pueden darle vida ${ }^{44}$.

siglos se han ido pudiendo ubicar más o menos, sólo a partir de datos procedentes de la Epigrafía (advirtiendo que alguna se me ha podido escapar).

42. Esto es: que por sus capacidades sepan sacar el mejor fruto del tiempo y los medios que gasten en su trabajo.

43. El encargo hubo de ser hecho o en 1784, aún bajo Carlos III, si entendemos que este Plan es la entera redacción de 1790 , fecha que aparece en el título, o bien mejor en 1791, ya con Carlos IV, si nos atenemos a la fecha de publicación, 1797, y a que el Plan fue actualizado y completado para publicarlo, como de algunos detalles se infiere.

44. En efecto, sólo el trono podía entonces auspiciar, y financiar, un viaje que abarcara toda la Península. 


\section{Itinerario y ruta de este viaje, con expresión de los pueblos y parajes donde hay cosas de su objeto ${ }^{45}$}

\section{CATAluña ${ }^{46}$.}

Ampurias. Llivia. Ripoll. Sarreal. Barcelona. Tarragona. Terrasa. Manresa. Martorell. Monserrate. San Miguel del Fay. Lérida.

\section{ARAGÓN ${ }^{47}$.}

Zaragoza. Monzon. Aliaga. Huesca. Jaca. Sos. Boltaña. Calatayud. Escatron. Tarazona. Ainsa. Exea. Ibedes. Loarre. Mallen. Caspe. Mirabete. Quinto. Teruel. Tiermas. Belilla. Zuera. Daroca. Sarrion.

\section{VALENCIA $^{48}$.}

Valencia. Palancia. Cabañas. Sagunto. Denia. Montesa. Morella. Peñíscola. Segorbe. Xérica. Onda. Xixona. Alicante. Orihuela. Sanfelipe ${ }^{49}$.

$$
\text { NAVARRA Y VIZCAYA }{ }^{50} \text {. }
$$

Fitero. Larraga. Lequeitio. Marañon. Miranda. Pamplona. Roncesvalles. Tudela. Olite.

$$
\text { ASTURIAS }^{51} \text {. }
$$

Corias. Oviedo. Cornellana. Avilés. Cangas de Onís. Covadonga. Luarca. Navia. Gijon. Naranco.

\section{GALICIA.}

Padron. Tui. Orense. Mondoñedo. Lugo. San-Payo. Pontevedra. Redondela. Ribadeo. Santiago.

45. Comienza aquí el interesante catálogo de ciudades y despoblados donde existían restos arqueológicos importantes para su estudio. Como ya dije, respeto todas sus grafías, en este caso también las faltas de acentos. Se observará que lo divide por los antiguos reinos y/o regiones españolas, pues no sería hasta 1833 cuando se implantaran las subdivisiones provinciales, tan perjudiciales a mi juicio para los estudios arqueológicos contemporáneos, en los que se continúan utilizando habitualmente. Como avancé, pongo ahora en notas al pie, para su cómodo cotejo, las ciudades o despoblados que incluyó Laborde en su Voyage, con objeto de que se aprecie mejor lo mucho más completo que era el Plan de J. Ortiz.

46. Laborde, vol. I: Barcelona, S. Miguel del Fay, Martorell, Montserrat, Olérdola, Tarragona, Tortosa, Lérida, Poblet, Bellpuig, Cardona, Manresa y Gerona. Laborde 13, Ortiz 12, coinciden en las 7 que resalto en negritas ( $u$ t infra).

47. Laborde, vol. IV: Sólo incluyó Zaragoza, y ninguno de los otros 23 yacimientos arqueológicos que da Ortiz.

48. Laborde, vol. II (Valencia, nada de Murcia, y Extremadura más Talavera, v. infra): Valencia, Murviedro, Almenara, Cabanes, Villafames, Chulilla, Chelves, San Felipe, Montesa, Dayemus [Daimuz], Denia, Calpe, Villa-Joyosa, Alicante y Elche. Laborde 15, Ortiz 15, y coinciden en 7; Ortiz olvida los interesantes mausoleos de Villajoyosa y Daimuz, que tenía que conocer sobradamente.

49. Sic. Játiva, cambiada de nombre por Felipe V, debido a su actitud antiborbónica durante la Guerra de Sucesión.

50. Laborde, vol. IV: De Navarra y País Vasco, Laborde sólo incluye Pamplona y Roncesvalles, mientras Ortiz ofrece 9 puntos más.

51. De los territorios de Asturias, Galicia y León Laborde no recogió nada. 
LEÓN.

Leon. Astorga. Carrion. Mayorga. Villalpando. Toro. Zamora. Palencia. Salamanca. Ciudad-Rodrigo. Alba. San-Felices. Ledesma.

\section{EXTREMADURA $^{52}$.}

Plasencia. Caparra. Villar. Aldea-nueva. Baños. Puerto de Baños. Oliva. Coria. Alcántara. Truxillo. Badajoz. La Puebla de la Calzada. Segura. Alhange. Zalamea de la Serena. Feria. Montijo. Mérida. Montanches. Medina de las Torres. Medellín. Valencia. Zafra.

\section{SEVILLA ${ }^{53}$.}

Sevilla $^{54}$. Itálica. Carmona. Alcocer. Cantillana. Ayamonte. El Rocadillo. Cazalla. Osuna. Niebla. Bejer. Bornos. Algecira. Xerez. Cabezas de San Juan. Porcuna. Cazlona ${ }^{55}$. Gelves. Alcolea. Cortegana. Lora. Marchena. Moron. Reyna. Rota. Tocina. Utrera.

\section{CÓRDOBA.}

Todo su territorio está sembrado de pueblos antiguos arruinados, especialmente entre los ríos Xenil y Betis, donde sucedieron los últimos sucesos de armas entre César y los hijos de Pompeyo. Es menester recorrerlo despacio ${ }^{56}$.

JAÉN.

Jaen. Baeza. Ubeda. Bilches. Xavalquinto. Higueruela. Marmolejo. Mengibas. Villa-nueva del Arzobispo. Ximena. Andujar.

\section{GRANADA.}

Granada. Setenil. Zahara. Málaga. Almuñecar. Comares. Muxacra ${ }^{57}$. Cártama. Antequera. Martos. Moncloa. Cabra. Verja. Salobreña. Baza. Benamexix. Estepa. Estepona. Marbella. Orgiba. Ronda. Vera. Guadix el viejo. Monda.

52. Laborde, vol. II (con Valencia): Badajoz, Mérida, Alconétar, Alcántara, Cáceres, Coria, Cápara, Talavera y Guadalupe. Laborde sólo 9, Ortiz 23, y coinciden en sólo 5 lugares, haciendo Laborde una demasiado severa selección; en cambio Ortiz olvida los restos del puente de Alconétar sobre el Tajo.

53. En consonancia con su definición previa de «las Andalucías», Ortiz divide la entonces región y actual Comunidad Autónoma en sus cuatro viejos reinos: Sevilla, Córdoba, Jaén y Granada.

54. Laborde, vol. III: Belmez, Espiel, Sierra Morena, Córdoba, Granada, Alhambra, Loja, Sevilla, Itálica, Málaga, Gibraltar y Cádiz. Frente a los 63 yacimientos que ofrece el anticuario español, Laborde reagrupa los cuatro reinos y sólo visita 12 lugares, entre ellos las 5 principales capitales. En cambio, de las otras 7 sólo coincide con Ortiz en Itálica.

55. Aquí sufre Ortiz un error, o una alteración involuntaria de sus papeletas, ya que Porcuna, al igual que el despoblado de Cazlona -que corresponde a la ciudad de Castulo, cerca de Linares, J.-, tenían que estar relacionados dentro del reino de Jaén y no aquí. Y allí, en efecto, faltan ambos.

56. El número de despoblados y pueblos modernos con restos romanos de la jurisdicción de Córdoba debía de ser desde luego tan extenso que renuncia a pormenorizarlo.

57. Interesante precedente lingüístico para la actual «Mojácar». 


\section{$\operatorname{MURCIA}^{58}$.}

Murcia. Cartagena. Lorca. Puerto de Aguilas. Segura ${ }^{59}$. Archena. Chinchilla. Sax. Tobarra. Villena ${ }^{60}$.

\section{Castilla la Vieja ${ }^{6 !}$.}

Burgos. Lara. Paredes. Peñafiel. Reynosa. Clunia. Soria. Saldaña. Valladolid. Pedraza. Salas. Calahorra. Sigüenza. Segovia. Abila. Coca. Castro-Xeriz. Guardia. Medina-Celi. Medina del Campo. San Millan. La Calzada. Logroño. Silos. Tordesillas. Ureña \&c.

\section{Castilla la Nueva.}

Alcaraz. Guisando. Toledo. Alarcon. Calatrava. Consuegra. Huete. Maqueda. Moya. Valera. Utiel.Zurita. Escalona. Molina. Cuenca \&c.

NOTA.

Como es imposible que el que viaja no mude de dictamen y rutas al tenor de las ocasiones y acasos que se le proporcionan en los caminos y pueblos, con las noticias adquiridas en ellos, no se ha tenido en cuenta en la colocación de los arriba nombrados ${ }^{62}$. Se reserva también para cuando este viaje se efectúe el aumentar su número a proporción de las noticias que darán los moradores y prácticos ${ }^{63}$ en los países.

\section{MADRID EN LA IMPRENTA REAL. AÑO DE 1797.}

[Fin del Plan de un Viage Arquitectónico-Antiquario de Fr. José F. Ortiz]

58. Laborde no visitó tampoco Murcia, ni siquiera el importante enclave de Cartagena, donde muchos restos romanos eran aún visibles, algunos de los cuales sí reportó a Godoy el espía F. de Zamora (Canto 2001, s.v.).

59. Ha de ser Segura de la Sierra, actualmente de Jaén pero en esta época aún del reino de Murcia.

60. Actualmente pertenece a la provincia de Alicante y Comunidad Valenciana.

61. Laborde, vol. IV (agrupado con Pamplona, Zaragoza y Castilla la Nueva): Burgos, Segovia, Talavera (Ortiz la da en Extremadura), Valladolid, Coca, San Ildefonso, El Escorial, Toledo, Aranjuez, Madrid, Ocaña, Granada. Ortiz da 26 lugares, mientras Laborde sólo 11 , coincidiendo apenas en los seis señalados. Pero no olvidemos que el francés no llevaba un interés tan específico por lo romano, y recogía también los mejores monumentos árabes y renacentistas.

62. Parece faltar alguna palabra, como «ello». Pero quiere decir que no ha tenido en cuenta los posibles cambios de ruta sobre la marcha, a raíz de las contingencias surgidas.

63. O sea, los buenos conocedores. 


\section{APORTACIONES DEL PROYECTO DE VIAJE ARQUEOLÓGICO DE J. ORTIZ Y SANZ A NUESTROS ACTUALES CONOCIMIENTOS}

El proyecto del P. Ortiz es de por sí bastante claro, y cada lector podrá extraer de él conclusiones e ideas a partir de su propia formación, de sus lugares de residencia o de sus propios trabajos arqueológicos e intereses científicos. Por ello sólo quiero trazar unas breves pinceladas sobre lo más general que su lectura puede sugerir para aproximarnos al estado de la Arqueología española a fines del siglo ilustrado. Aunque ya puede imaginar quien esto lea que, al elegir este texto para, después de 200 años, volverlo a poner al alcance de un público tan diferente, y arqueológicamente mucho más cultivado que el que en su época podía leer al sabio fraile, ya me ha guiado la idea de que, en efecto, su lectura podía aportarnos algunas ideas de interés y datos nuevos. Tanto para evaluar el nivel de los conocimientos arqueológicos a fines del siglo XVIII, como la utilidad que a esta ciencia veían los expertos (los «doctos, eruditos, literatos», como él los llama), como, y muy especialmente, para conocer los yacimientos que cita en su personal itinerario. Porque son éstos sin duda los que contaban con más restos arqueológicos interesantes en su época, de los tipos que él cita, y me ha llamado la atención la cantidad de ellos que no están ya actualmente «en circulación». El panorama de la Arqueología y los arqueólogos a fines del siglo XVIII que Ortiz nos presenta, sólo a partir de este breve proyecto, es más o menos como sigue:

1) Cualidades y conocimientos del arqueólogo. Frente a las acusaciones bastante generalizadas de la opinión europea de que los españoles eran indolentes hacia las anitigüedades y ni siquiera sabían reconocer su valor, Ortiz acepta sólo la primera de ellas. Con la cita de una larga lista de eruditos, que encabezan Ocampo, Morales y Nebrija, quiere acreditar que los españoles (y portugueses), al menos desde el siglo XVI, sí sabían valorar los monumentos antiguos, pero que para «descubrirlos, ilustrarlos y publicarlos» eran precisas personas versadas en el tema, que tuvieran genio y constancia; y que para su tarea necesitaban años de trabajo y bastantes caudales, que normalmente no tenían. La necesidad de la ilustración o dibujo de los monumentos era grande, pero por lo general no se sabía hacer con calidad, y seguramente era ésta la causa por la que Montfaucon, a comienzos del siglo, no había publicado en su magna enciclopedia muchos de los dibujos hispanos que el deán Martí le enviara. Porque el arqueólogo, en efecto, debe saber dibujar y medir artísticamente y con inteligencia de partes.

2) Las ciencias arqueológicas de la época. Tras una patriótica, severa y detallada diatriba acerca del mal estado en que en italianos y franceses conservaban muchos valiosos vestigios y cómo tampoco allí era achacable a los anticuarios mismos, pasa a detallar qué aspectos deben ser considerados en un viaje arqueológico de España, con lo que nos ofrece una imagen de las ciencias arqueológicas de la época y de la utilidad de cada una. Son las que un arqueólogo debe conocer y dominar, por este orden: Arquitectura, Escultura, Musivaria, Medallas (Numismática), Inscripciones (Epigrafía), de las que dice que «son uno de los lugares históricos más estimados y seguros») y, por fin, la Geografía Histórica. Al tratar de esta especialidad histórico-arqueológica (lamentablemente ausente, como la Historia Antigua misma, de nuestros «modernos» planes de estudio) incluye una interesante relación de las ciudades hispanorromanas conocidas por las fuentes, pero cuya localización era en su época discutida o desconocida (sobre la que, como dije, no me es posible detenerme ahora). Nos indica también la cantidad de poblaciones antiguas muy grandes medio sepultadas en sus ruinas, que, singularmente en Extremadura y las Andalucías, era dado contemplar a los viajeros, con gran disgusto por su abandono y el peligro en el que se hallaban. 
3) Sacrificios y trabajos del arqueólogo ilustrado. Tras relacionar los muchos lugares antiguos hispanorromanos cuya ubicación o identificación no se conocía, y la necesidad que había de investigar y excavar para averiguarlos, señala lo difícil de encontrar personas idóneas, que estén dispuestas a gastar su dinero y su tiempo, dejando la paz y comodidad de sus casas y emprendiendo preocupaciones y viajes muy penosos. Su trabajo consistiría en: desmontar ruinas, descubrir suelos, subir sobre los acueductos, paredones y demás monumentos, hacer indagaciones, tomar medidas, levantar planos, perfiles y vistas, combinar partes, averiguar proporciones, dibujar cuanto convenga, sacar partido de cada miembro, de cada moldura; con otras muchas cosas que las circunstancias aconsejen.

4) La biblioteca del historiador y arqueólogo del XVIII. A lo largo del libro, J. Ortiz va citando elogiosamente a diversos autores, cuyas obras son sin duda las que tenían que conocer y manejar, como mínimo, los anticuarios de la época. Podemos inferir, pues, que la biblioteca básica de un historiador y arqueólogo del XVIII incluiría las publicaciones señeras de ${ }^{64}$ : Florián de Ocampo (1544), Ambrosio de Morales (1575), Elio Antonio de Nebrija (1502), Luis Núñez, de Antwerp (1607), Luis A. Resende (1593), Juan Luis Vives (1520), Juan Arfe de Villafañe (1585), Antonio Agustín (1587), Juan de Mariana (1592), Pedro Chacón (1580), Francisco Llanzol de Romaní (1540), Martín de Roa (1636), Rodrigo Caro (1634), Juan Francisco Andrés de Ustarroz (1638), Juan Lorenzo Palmireno (1565), G. Ibáñez de Segovia, marqués de Mondéjar (1666), Nicolás Antonio (1652), Manuel Martí (1737), Gregorio Mayans y Ciscar (1742), Enrique Flórez (1775), Luis J. de Velázquez, marqués de Valdeflores (1765), Francisco Pérez Bayer (1782), A. Valcárcel Pío de Saboya, conde de Lumiares (1786) y, entre los extranjeros, la grandiosa L'Antiquité expliquée de Bernard de Montfaucon (1719) y los corpora epigráficos de Jan Gruter (1603), Raffaello Fabretti (1699) y Ludovico Muratori (1739).

A sensu contrario, nuestro canónigo descalifica por completo las obras de otra serie de viajeros extranjeros, cuyos escritos e impresiones sobre España le parecían llenos de falsedades y poco fiables. Entre éstos cita expresamente, sólo por su apellido u obra (que también he procurado completar aquí), a E. Clark $(1763)^{65}$, N. Caimo $(1759)^{66}$, J.-B. Fleuriot Figaro $(1784)^{67}$, lord Swinburne ${ }^{68}(1779)$, el marqués d'Argens $(1764)^{69}$, Ch.-P. Coste $(1756)^{70}$, y las Cartas Persianas de Montesquieu ${ }^{71}$.

En cuanto a fuentes históricas antiguas, había que conocer las obras de (según los cita): Polibio, Diodoro, Livio, César, Mela, Estrabón, Plinio, Suetonio, Dión Casio, el Itinerario de Antonino ${ }^{72}$, Ptolomeo y Estéfano (scil., Esteban de Bizancio), además de los concilios, las historias medievales y los códigos legales.

64. Completo todos sus nombres y los años de sus principales obras (excepto a Arfe que, citado en otro párrafo, inserto en su época) y los dejo en el mismo orden, aproximadamente sucesivo, en el que el autor los cita.

65. E. Clarke, Letters concerning the Spanish Nation, written at Madrid during the years 1760 and 1761, Londres 1763.

66. N. Caimo, Lettere d'un viaggiatore italiano ad un suo amico, vol. 1, Lucca, 1759.

67. J.-M.-J. Fleuriot de Langle, al. Figaro, Voyage de Figaro, en Espagne, Saint Malo 1784 (se publicó también en Sevilla, en 1785 , asimismo con nombre y direcciones falsas).

68. H. Swinburne, Viaje por España en los años 1775 y 1776. En el cual diversos monumentos de arquitectura romana yárabe han sido ilustrados por medio de detallados dibujos tomados al natural, Londres 1779.

69. J.-B. de Boyer, marqués de Argens, Lettres Juives, ou Correspondance Philosophique, historique \& critique, entre un Juif Voyageur en différents Etats de l'Europe, \& ses Correspondants en divers endroits, La Haya 1764 (esp. It. III-IV). No es extraño: se trata de un autor ilustrado que se distinguió especialmente por su anticlericalismo.

70. Ch.-P. Coste d'Arnobat, Lettres sur le voyage d'Espagne, por M. xxx, Pamplona 1756. Era un individuo de Bayona muy poco recomendable, al decir de Fléron.

71. Ch.-L. de Secondat, barón de Montesquieu, Lettres Persanes, Amsterdam 1721. Ortiz no cita al autor, pero tiene que ser Montesquieu, por más que me parece que en esta obra no hace tantas alusiones críticas a España.

72. A esta importante fuente itineraria se ha de referir, bajo el nombre erróneo Antonio Pío del heredero de Adriano. 
5) Los objetos de interés del arqueólogo. Son muy variados: En lo que afecta a la toponimia, sobre todo interesa poder identificar por su nombre las ruinas de las ciudades antiguas y su época. En Arquitectura, medir y levantar correctamente los planos de los edificios y poder reconstruir su aspecto original, separando lo existente de lo imaginado, y conocer e identificar bien los materiales, sus técnicas y épocas. El principal objeto al excavar o «descubrir» -así lo llama en otras dos ocasiones, y en verdad muy propiamente- era liberar los edificios. En cuanto a la restauración de las ruinas, nada se preveía; al contrario, afirma que conviene seleccionar las mejores piezas y, con permiso del rey, trasladarlas a la Real Academia de San Fernando para que sirvan de instrucción a los estudiantes de Arquitectura. La Escultura servirá para múltiples estudios de dioses, rituales, vestidos, calzados, armas e instrumentos, todo ello para mejor inteligencia de la Historia Antigua. Los mosaycos son útiles a la Historia, Mitología y Nobles Artes. Las monedas interesan para la Cronología, la Geografía y, en fin, la Historia. Y, por lo que respecta a las inscripciones, afirma que nunca en España se han buscado a propósito, pero que el azar proporciona muchas, pasando a continuación a dar una relación, la más detallada de la serie, de los innumerables tipos de información que aportan, concluyendo, con mucho acierto, que sin las inscripciones ignoraríamos lo mejor de la Antigüedad.

6) Otras cuestiones. En cuanto a las fuentes de financiación, a lo largo del proyecto de J. Ortiz queda claro que estudios de esta magnitud sólo podían ser sufragados por los monarcas, de los que además debían de venir necesariamente los permisos y pases. Ni siquiera los grandes nobles, la Iglesia ${ }^{73}$, las universidades o las academias tenían al parecer medios, y para todo se dependía del rey; aunque, dado el sistema absolutista, tampoco es de extrañar. La noticia de los monetarios privados es también interesante, por cuanto los particulares también los formaban, y, en esta época ya con criterios de catalogación, según creo se puede entender de su frase de que «las coordinaban en ellos». Es una pena también que no se llevara a cabo la propuesta de Ortiz, desde Roma, de formar en Madrid un «Museo de vaciados arquitectónicos», del mismo modo que sí se llegó a hacer, y fue y es aún de gran utilidad, el de vaciados escultóricos.

7) El catálogo de los yacimientos arqueológicos hispanorromanos conocidos en su tiempo. Quizá sea lo más interesante de este folleto la relación del itinerario y ruta que fray José Ortiz proponía para estudiar aquellos lugares de España que contaban con ruinas visibles o hallazgos, y especialmente arquitectónicos (no olvidemos que ése era su principal interés), en cantidad suficiente como para merecer una parada en el Viaje anticuario. Algunos yacimientos nos los señala como riquísimos en hallazgos casuales: Mérida, Sagunto, Clunia, Andújar, Cáparra, Cabeza de Griego (Segobriga) y Toledo, aparte de los mosaicos de Barcelona, Rielves, Jumilla y Valencia. Todos aquellos, en efecto, siguen siendo fértiles, y en todos se han ido realizando luego excavaciones, y las de Mérida, Sagunto y Segóbriga ya en su época, a las propias expensas del rey Carlos IV (Canto 2001 a y b).

Esta «Carta arqueológica de la España romana» del siglo XVIII arroja la asombrosa cifra de 229 yacimientos, y ello sin contar los muy numerosos del territorio de Córdoba, que Ortiz no detalló. El total fácilmente llegaría a los 275. El cálculo por cada antiguo reino o territorio queda así: Cataluña 12, Aragón 24, Navarra y Vizcaya 9, Asturias 10, Galicia 10, León 13, Extremadura 23, Sevilla 27, Córdoba passim, Jaén 11, Granada 24, Murcia 10, Castilla la Vieja 26 y Castilla la Nueva 15.

73. La Iglesia podía a veces autorizar y pagar pequeñas excavaciones en el entorno o en el interior de determinados templos, buscando las antiguas basílicas cristianas o las reliquias fundacionales, como en la experiencia que el deán relata (ut supra) en Játiva. 
Muchos de ellos son célebres y cuentan ahora con sus propios equipos de excavación, museos y centros de estudio, en general las grandes capitales (Tarragona, Barcelona, Mérida, Sevilla, Valencia, Alicante, Toledo...). Otros han sido estudiados en alguna medida o aspecto, pero el proceso de crecimiento urbano de entonces acá, y en especial en el último cuarto del siglo XX, ha hecho cada vez más difícil, o imposible, su estudio en profundidad. Grandes monumentos más aislados, como los arcos de Medinaceli y Cabanes, o los puentes de Alcántara y Martorell, siguen afortunadamente en su lugar, más deteriorados ellos mismos por el tiempo, pero mucho mejor tratados en su entorno y valoración. Otros muchísimos yacimientos, sin embargo, han desaparecido literalmente de la historiografía y de los hallazgos (aunque ello se haya compensado con otros nuevos, no conocidos en época de Ortiz).

He hecho una cata, a modo indicativo, comparando los yacimientos citados por el canónigo en las provincias andaluzas con el índice de lugares de la catalogación de Hispania, debida al Instituto Arqueológico Alemán (VV.AA. 1993: 483-489), donde están muy bien reunidas todas las notabilia hispanorromanas en arquitectura, urbanismo y escultura. Es un método alternativo, de «andar por casa» y sin afán alguno de precisión (ya que Ortiz mismo dice que a veces estudiará edificios notables árabes y modernos, pero éstos suelen estar en las grandes capitales), que se me ocurre a bote pronto para sugerir el interés actual del catálogo de Fray J. Ortiz. El resultado es que de los 63 yacimientos andaluces recogidos por el deán (sin los de Córdoba, recuerdo), de nada menos que 42 , dos tercios exactos, ya no tenemos hoy noticias de notables restos arquitectónicos o hallazgos conservados, que existían hacia 1790 y estaban catalogados como de mérito por alguna o varias fuentes.

Para otro tipo de utilidad, más indirecta y concreta si se quiere, llamaré la atención sobre la referencia a Cortegana, en Huelva: Se recordará que hace tiempo defendí que de allí tenía que proceder, mejor que de Itálica, el hasta entonces llamado fragmentum Italicense de ley flavia municipal ${ }^{74}$. J. González, que no creía en ello, lo rebatió ( $c f$. CILA 3: 16, con la bibliografía anterior), argumentando sobre todo que aquel municipio onubense lo tenía él bien prospectado, no existiendo resto alguno que pudiera corresponder a una ciudad. Sin saber incluso de cuáles tenía Ortiz noticias concretas en esa época, y habida cuenta de la dificultad que por entonces presentaba el llegar hasta este pueblo serrano, me parece que su inclusión en el Viaje confirma que a fines del XVIII algunos restos arquitectónicos sí se veían en Cortegana, y de la suficiente entidad.

Parece clara la necesidad de volver sobre las noticias antiguas acerca de todos esos lugares. Para ello tenemos varias vías, que son las que sugiero, pero todas afectan a la Historiografía, cuya gran utilidad moderna está ahora en plena revalorización. El trabajo que se quiera hacer a partir de esta casi inédita carta arqueológica del XVIII tendrá que comprobar, pues, todas las fuentes que Ortiz y Sanz tuvo presentes para elaborar su itinerario de ruinas notables españolas. En primer lugar lo serían todos los autores españoles que cita y que más atrás detallé, junto a otras referencias expresas de publicaciones (como «...La Academia de Buenas Letras de Sevilla, el Maestro Fray Enrique Florez, los historiadores de algunas ciudades y pueblos en particular, y algunos otros sabios, han dado también al público varios restos antiguos...»). Pero las principales a mi juicio serían sus informaciones no publicadas (dejando a un lado a los «testigos» que cita alguna vez). Dado que, de momento, parece claro que los viajes de Ortiz, excepto el de Italia, siempre fueron por las cercanías de Madrid, o entre Madrid y Valencia, hay que concluir que sus principales fuentes de suministro de datos fueron tres. En primer lugar, la Real Biblioteca, en la que él trabajó durante años. Era éste un

74. Me pareció más de fiar la información del arqueólogo francés A. Engel sobre su origen, y el hecho de que ese estatuto inferior para Itálica en plena época flavia no era acorde con su antigua estirpe romana o su rico repertorio de amonedaciones augusteas, ni con estar la ciudad en esos tiempos ya en las vísperas de sentar a un italicense en el trono. 
observatorio excepcional, al que, además de infinitos manuscritos, llegaban numerosas noticias de hallazgos de los que se informaba al rey. El segundo serían los fondos, tanto impresos como documentales, y los informes y referencias modernas de hallazgos, de la Real Academia de la Historia, que frecuentaría ya antes de su ingreso en ella en 1801, y que desde su fundación, pero más desde la creación de la Sala de Antiguiedades en 1792, había ido concentrando todas las noticias de la Arqueología española (de cuyos hallazgos tenían además obligación de informar), así como las papeletas de algunos proyectos inconclusos, como el famoso Diccionario Geográfico. El tercero, sin duda, la Real Academia de San Fernando, con la que siempre mantuvo una estrecha relación, reforzada en este caso por sus intereses especiales en los estudios de Arquitectura. En todos estos lugares, puedo adelantarlo, quedan las huellas del trabajo de nuestro deán arqueólogo, cuya explotación por la arqueología contemporánea ha sido en general casi nula.

Afortunadamente, al día de hoy los fondos manuscritos de las dos primeras instituciones citadas han sido ya completamente catalogados, como es el caso de la Real Biblioteca ${ }^{75}$, o están en proceso de serlo, en los casos de las dos Reales Academias. La de la Historia lleva más avanzadas sus publicaciones de los fondos de la Comisión de Antigüedades pero al ser ésta más reciente y haber trabajado de forma no muy regular, su información resulta ser más moderna y a veces, si se quiere, más burocrática ${ }^{76}$. Será de mucho más interés para nuestro propósito la catalogación de los manuscritos, informes, estudios parciales, ensayos, cartas y notificaciones a los académicos que componen aquel riquísimo banco de datos para la Arqueología española; pero, mientras, los documentos están allí y son un apasionante reto para investigadores idóneos y pacientes.

Sólo dos palabras ya para algo que en su día quedé en comprobar: Las no muchas coincidencias existentes entre el Viaje de Ortiz y el Voyage de Laborde (e incluso con su Itinéraire descriptif de l'Espagne) no confirman finalmente los temores del canónigo de que su Plan podría ser copiado por Laborde: el proyecto completo del presbítero no era el tipo de viaje que interesaba al gran público, ni había laborde capaz de hacerlo...

Termino aquí con la sensación de haber abusado de todos modos del espacio concedido, y quizá también de la paciencia del lector, pero con la esperanza de haber contribuido a varios fines $y$, sobre todo, al homenaje simultáneo de dos valiosas figuras de nuestra Arqueología nacional.

75. Se publicó ya un catálogo en nueve volúmenes entre 1898 y 1928. La labor se continúa actualmente, bajo la dirección de $\mathrm{M}^{\mathrm{a}} \mathrm{L}$. López Vidriero, con los tomos 10 y ss., varios volúmenes, de manuscritos, índices, etc., Madrid, 1994 ss.

76. Una cata informal hecha en el volumen correspondiente a Aragón (Maier y Álvarez Sanchís 1999) indica que, de los 23 municipios referenciados por el canónigo, en la Comisión sólo hay documentos sobre 12, y además prácticamente todos ellos corresponden a iglesias y monasterios medievales y modernos. 


\section{BIBLIOGRAFÍA ABREVIADA}

CANTO, A. Ma (1994): «Un precursor hispano del CIL en el siglo XVIII: El Marqués de Valdeflores», Boletín de la Real Academia de la Historia CXCI: 499-516.

: :La Arqueología española bajo Carlos IV y Godoy: Preludio a los dibujos emeritenses de Villena Moziño (1791-1794)», Anas 7-8 (Homenaje a J. Álvarez y S. de Buruaga): 31-56.

(1999): «llorci, Scipionis rogus (Plinio, NH, III, 9) y algunos problemas de la Segunda Guerra Púnica en Hispania», Rivista Storica dell'Antichità, XXIX: 127-167.

- (2001a): La Arqueología española en la época de Carlos IV y Godoy. Los dibujos de Mérida de don Manuel de Villena Moziño, 1791-1794 (Fundaciones de Estudios Romanos y El Monte), Madrid.

- (2001b): Mérida y la Arqueología Ilustrada: Las láminas de don Manuel de Villena (1791-1794), catálogo de la exposición en el Museo Nacional de Arte Romano de Mérida junio-octubre de 2001 (Ministerio de Educación y Cultura), Madrid.

- (e. e.): El viaje del caballeroinglés John Breval a España y Portugal, en 1726. Novedades arqueológicas y epigráficas del siglo XVIII, en elaboración.

CHATEAUBRIAND, F.-R. de (1807): «Voyage pittoresque et historique de l'Espagne, par M. de Laborde», reseña en Le Mercure de France, t. XXIX, 4 de julio, 7-21.

CHOISEUL-GOUFFIER, M. G. A. (1782): Voyage Pittoresque de la Grèce, tomo I (tomos II y III: 1809 y 1822), París.

CUBILES FERNÁNDEZ, S. (1983): Los grabados de arquitectura y la Imprenta Real bajo los reinados de Carlos III y Carlos IV (tesis doctoral dactilografiada), Madrid.

ENGUÍDANOS (1824/1921): S. (López) Enguídanos y Ortiz, «Resumen de los méritos, títulos, grados, etc. de don José Ortiz...» (ms de 1824, publicado en 1921), Boletín de la Real Academia de la Historia LXXXIX, 1921, 362-368.

GOBERNA (1988): F. Goberna Ortiz, «Ante los doscientos cincuenta años del nacimiento del deán Ortiz en Ayelo de Malferit (1739-1989)», Estudis i Documents IV (Ontinyent), 82-89.

(1998): id., «El degà de Xàtiva Joseph Ortiz i Sanz (1739-1922)», Papers de la Costera (Xàtiva), abril de 1998, 70-90.

- (2001): id., El degà Ortiz i Sanz. La seua vida iobra (col. Biblioteca Degà Ortizi i Sanz, nº 1), Ajuntament d'Aielo de Malferit (Valencia).

GODOY, M., PRÍNCIPE DE LA PAZ (1836): [Cuenta dada de su vida política por don Manuel Godoy, Príncipe de la Paz.] Memorias críticas y apologéticas para la historia del reinado del Señor D. Carlos IV de Borbón, edición y estudio preliminar de C. Seco Serrano (Biblioteca de Autores Españoles núms. 88 y 89), Madrid, 1965 (ed. francesa: París, 1836, en 4 vols., edición española en $8^{\circ}$ en 6 vols., y traducción de la francesa con Introducción de Mr. Esménard, en $4^{\circ}$, Madrid, 1836).

LARA ORTEGA, S. (1991): El teatro romano de Sagunto: génesis y construcción, Valencia.

MAIER, J. y ÁLVAREZ-SANCHÍS, J. (1999): Comisión de Antigüedades de la Real Academia de la Historia. Aragón. Catálogo e índices, Madrid.

MATILLA, J.M. (1997): «José Ortiz y Sanz y la normalización de la arqueología», en: VV.AA., Anticuaria y Arqueología. Imágenes de la España Antigua 1757-1877 (catálogo de las exposiciones en Milán, Nápoles y Roma, 1997), Madrid: 41-50.

MORA, G. (1998): Historias de mármol. La arqueología clásica española en el siglo XVIII (Anejos de AEspA $\left.\mathrm{n}^{\circ} \mathrm{XVIII}\right)$, Madrid.

ORTIZ Y SANZ, J. (1787): Tratado de Arquitectura de Vitruvio, Madrid (reediciones del C.O. de Aparejadores de Almería [1974]; Madrid [1987]; Lugo [1989]; del Colegio Oficial de Arquitectos de 
Madrid, con introducción y edición de D. Rodríguez Ruiz, Madrid [1991]; de la editorial Alta Fulla, Barcelona, 1993 (eiusd.); y de Akal, Madrid [1992 y 2001]).

- (1791-1796): Continuación de la Historia de España de D. Juan de Mariana (1537-1624), tomos VII, VIII y IX (ilustraciones, notas críticas y apéndice por...), Valencia.

(1792): Los diez libros de Diógenes Laercio sobre las vidas, opiniones y sentencias de los filósofos más ilustres / Traduzidos de la lengua griega e ilustrados con algunas notas por D. Josef Ortiz y Sanz, tt. I [-II], Madrid, Imprenta Real (reediciones con diferentes títulos: Madrid, 1904-1905, 1940, 1959, 1964 y 1973, México, 1984 y Barcelona, 1962 y 2000).

(1793): El azote de tunos, holgazanes y vagabundos: obrita útil a todos, en la qual se descubren los engaños y fraudes de los que corren el mundo a costa agena : refiérense muchísimos casos acontecidos en materia de vagos para desengaño e instrucción de la gente sencilla y crédula, traducción libre de la lengua toscana por $\mathrm{D}($ on) $\mathrm{J}$ (osé) $\mathrm{O}$ (rtiz), Madrid (reeditada en 1802, 1803 [ampliada] y por la Librería París-Valencia, 1999).

(1795-1803): Compendio cronológico de la Historia de España, desde los tiempos mas remotos hasta nuestros dias, tt. I-VII (reed. con un-suplemento hasta 1843: Madrid, 1841-1842).

(1796-1802): Nueva Historia General de España, 8 vol., Madrid (reed. 1846).

(1797a): Tratado de Arquitectura de Andrea Palladio (I), Madrid (reediciones por el Colegio Oficial de Arquitectos de Madrid, 1991 y la editorial Alta Fulla, Barcelona, 1993).

(1797b): Noticia y plan de un viage arquitectónico-anticuario encargado por Su Majestad a Don José Ortiz Sanz, el año de 1790, Madrid (reed. en microforma: Universidad de Valencia, septiembre de 1995).

(1807): Viage arquitectónico-anticuario de España (I), Madrid (reed. Valencia, 1976) ${ }^{77}$.

(1812): [Antigüedades de Sagunto]. Respuesta del doctor Ortiz, deán de la Insigne Colegial de la Ciudad de Xátiba, a la Carta que le dirigió D. Enrique Palos y Navarro, juez conservador de todas las antigüedades de Sagunto, Valencia (reeditada por el Centro Arqueológico Saguntino, 1975 y por la Librería París-Valencia, 1978).

(1817): Discurso histórico acerca de la legión llamada «Fulminante» en el imperio de Marco Aurelio el filósofo, Valencia (reeditado por S. Perea, en la serie Signifer, Madrid, 2002, en prensa).

(1820): Carta misiva del deán de Xàtiba a don Vicente Pla y Cabrera... dase en ella la interpretación de una lápida romana hallada en Valencia el año de 1807, Valencia.

(1849p): Compendio histórico del cisma grande de Occidente: obra póstuma de..., Alcoy.

(1862p): Disertación histórico-geográfica acerca del parage de la célebre ciudad de Munda. Obra póstuma de... precedida de una advertencia por D. Salvador Enguidanos, Madrid.

(1986p): Instituciones de Arquitectura civil, acomodadas en lo posible a la doctrina de Vitruvio, edición del manuscrito inédito del C.O.A.M. (antigua colección Marañón), con estudio introductorio de D. Rodríguez Ruiz, Madrid.

PALOS Y NAVARRO, E. (1793): Disertación sobre el teatro y circo de Sagunto, ahora villa de Murviedro, Valencia.

VV.AA. (1993): W. Trillmich et al., Hispania Antiqua. Denkmäler der Römerzeit (Deutsches Archäologisches Institut, Abteilung Madrid), Maguncia.

77. En Madrid, del original, conozco un ejemplar en la Real Academia de la Historia (sign. 14-3-1/1096); en cambio el de la Biblioteca Nacional (sign. VC $383 \mathrm{n}^{\circ}$ 95) se halla perdido. El que he usado, del Archivo Histórico Nacional, como dije, está dentro del expediente del autor (Estado leg. 3244), junto con una versión manuscrita, anterior y ligeramente distinta. Se localiza otro más entre los fondos antiguos de la biblioteca del Instituto Nacional de Educación Física. 